Originalveröffentlichung in: Melion, Walter S. ; Clifton, James ; Weemans, Michel (Hrsgg.): Imago exegetica. Visual images as exegetical instruments, 1400 - 1700 ; Emory University, Lovis Corinth Colloquium IV. Leiden ; Boston 2014, S. 737-790 (Intersections ; 33)

\title{
OF CHURCHES, HERETICS, AND OTHER GUIDES OF THE BLIND: THE FALL OF THE BLIND LEADING THE BLIND BY PIETER BRUEGEL THE ELDER AND THE ESTHETICS OF SUBVERSION*
}

\author{
Jürgen Müller
}

\section{Heresy in Pictures}

Pictures are a medium of biblical exegesis. By illustrating biblical subjects, they provide a specific interpretation of selected passages, clarifying and disambiguating by means of images, even where Scripture is vague or obscure. This is due first of all to the nature of the texts in the Old and New Testaments: one rarely encounters descriptions of persons and events vivid enough to function as precise templates for pictorial compositions. Pictures, on the other hand, are subject to the necessity of putting something in concrete form; as such, they require legitimization and are potentially instruments of codification. ${ }^{1}$

During the Reformation pictures were used to canonize religious viewpoints and to give expression to various orthodoxies, but also to denounce the heterodoxy of the opposing side. But whatever their function in religious practice may have been, as a rule they operated as vehicles of disambiguation. Luther, in particular, valued pictures as a pedagogical tool and took a critical stance against the iconoclasts. ${ }^{2}$ For him, their essential purpose was to teach, simply and clearly. ${ }^{3}$

Melion. Translated from German to English by Rosemarie Greenman and edited by Walter 1 Cf.

83-106.

${ }^{2}$ Cf. Berns J.J., "Die Macht der äußeren und der inneren Bilder. Momente des innerpro-

keit und Bild Bilderstreits während der Reformation", in Battafarano I.M. (ed.), Begrifflich-

${ }^{3}$ und Bildlichkeit der Reformation (Bern: 1992) 9-37.

[exh. For a general overview, see Hofmann W. (ed.), Luther und die Folgen für die Kunst

bare Worte Hamburger Kunsthalle] (Munich: 1983); Warnke C.P., Sprechende Bilder, sicht-

"A tröstlite. Das Bildverständnis in der Frühen Neuzeit (Wiesbaden: 1987); Bergmann R.,

ormation 5 Picture: Luther's Attitude in the Question of Images", Renaissance and Ref-

Texten 5 (1981) 15-25; and Münch B.U., Geteiltes Leid. Die Passion Christi in Bildern und

Großprojekt Konfessionalisierung. Druckgraphik von der Reformation bis zu den jesuitischen Bprojekten um 1600 (Regensburg: 2009) 51-53. 
In the following remarks, I would like to explore the reverse case and present pictures as agents of subversion. For the interpreter this involves a search not for certainty, but for ambiguity or equivocality. In this context, semantic ambivalence is not to be construed as an expression of a modern concept of art in the sense of Umberto Eco's Open Work; rather, it signifies that a heterodox meaning is hidden or, better, embedded in the pictures. Thus my first thesis is that subversive pictures contain both an esoteric and an exoteric meaning. They address a group that would have been familiar with the practice of religious dissimulatio and capable of distinguishing between the actual and the spurious message. ${ }^{4}$

I shall utilize two pictures by Pieter Bruegel to illustrate this hypothesis of religious dissimulatio, both of which deal with the subject of religious deviance. To this end, I will first need to introduce Sebastian Brant's thoughts regarding 'religious pertinacity' in the Ship of Fools [Fig. 1]. Then I will analyze Bruegel's panel The Peasant and the Birdnester [Fig. 2] and his Tüchlein (glue-tempera painting) The Fall of the Blind Leading the Blind, dating from 1568 and addressing complementary issues [Fig. 3]. My aim is to show that these pictures, rather than taking an orthodox position, instead espouse the point of view of the 'deviationists' in a manner full of allusions.

Until now, little attention has been paid to the fact that Sebastian Brant in his 1494 Ship of Fools devoted a chapter to religious pertinacity. Accordingly, the Early New High German title of chapter 36 is 'Eygenrichtikeit' (pertinacity; literally, self-righteousness) [Fig. 1].5 The illustration shows a foolish nest robber falling from a tree top; the ground is strewn with dying birds thrown from their nests by the careless thief. The associated verse reads as follows: 'Whoever wants to fly away following his own mind / Trying to get bird-nests, / Will often find himself lying on the ground'. ('Wer will auf eignen Sinn ausfliegen / Und Vogelnester sucht $\mathfrak{Z}^{\mathfrak{l}}$ kriegen, / Der wird oft auf der Erde liegen'.) ${ }^{6}$ The invention of this curious allegory is attributed to Brant, but the question, does this allegory refer

4 I refer to my own research here: Müller J., Das Paradox als Bildform. Studien 2 2ur Ikonologie Pieter Bruegels d. Ä. (Munich: 1999); and idem, "Ein anderer Laokoon - Mijler' Geburt ästhetischer Subversion aus dem Geist der Reformation", in Kellner B. - Mult 6 . J.D. - Strohschneider P. (eds.), Erzählen und Episteme: Literaturgeschichte des späten 10 Jahrhunderts (Berlin-New York: 2011) 389-455.

${ }_{5}$ Brant S., Narrenschiff, ed. F. Zarncke (Darmstadt: 1964). See also Knape J. - Wuttke ${ }^{\text {D. }}$ Sebastian-Brant-Bibliographie. Forschungstiteratur von 1800 bis 1985 (Tübingen: $199^{\circ}$ ); ${ }^{\text {n }}$ Wilhelmi T., Sebastian Brant Bibliographie (Bern: 1990).

${ }^{6}$ Brant, Narrenschiff 38 . 
an.



Fig. 1. "Chapter 36: Von Eygenrichtikeit". Woodcut illustration to Sebastian Brant, Ship of Fools (Basel, Johann Bergmann von Olpe: 1494). 




Fig. 2. Pieter Bruegel the Elder, The Peasant and the Birdnester (1568). Oil on panel, $59 \times 68 \mathrm{~cm}$. Vienna, Kunsthistorisches Museum.

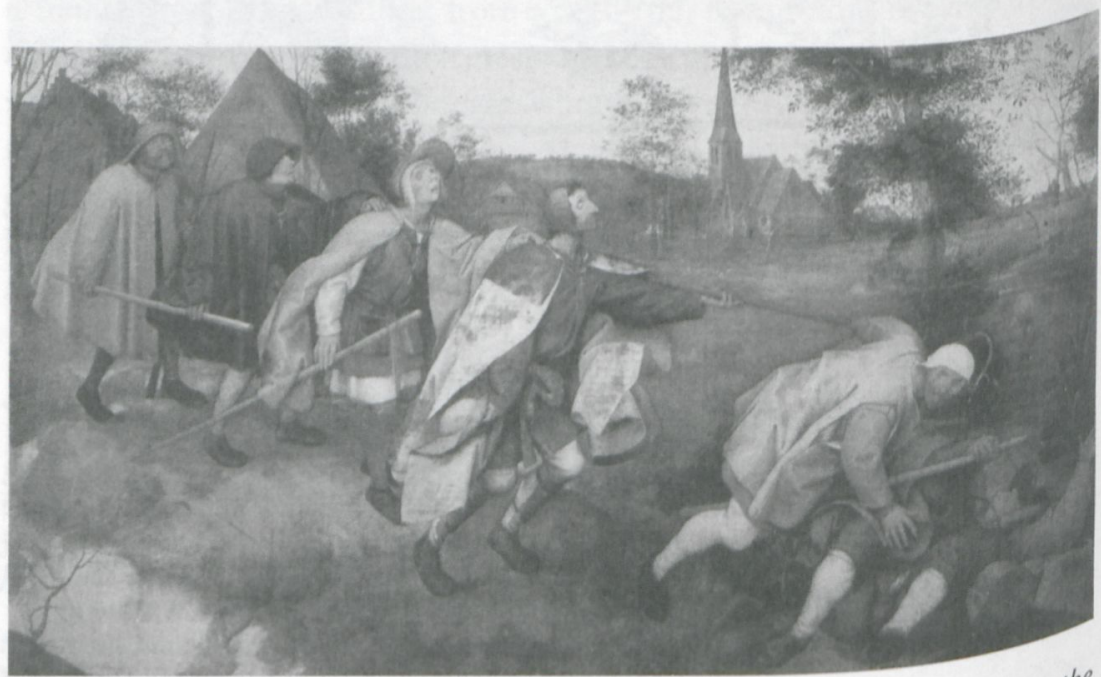

Fig. 3. [CoL. PL. 21] Pieter Bruegel the Elder, The Fall of the Blind Leading the Blind (1568). Oil on canvas, $86 \times 154 \mathrm{~cm}$. Naples, Museo e Gallerie Nazionali Capodimonte. 
to an existing tradition of imagery, has yet to be posed, and I shall now attempt to explore it. First off, it is of interest in our context to consider how a pre-Reformation 'Schlagbild' (key image) of heresy might look.

The beginning of the text describes people who have left the right path and do not notice that they have lost their way and gone astray. From the very first verses the humanist emphasizes the pertinacity of such people who consider themselves clever and shrewd: convinced that they need no help from anyone, they suddenly realize that there is no turning back from the place of self-inflicted isolation. With the words, 'Woe to him who falls and finds himself alone!' ('Weh dem, der fällt und ist allein!') the text reaches a first climax. ${ }^{7}$

The fifth verse teaches us about the consequences of false pertinacity: 'Often turned into heretics were those / Who would not be taught through just admonition, / Who relied on their own skill, / So that they might achieve fame and favor'. ('Zu Ketzern wurden oft verkehrt, / Die rechter Tadel nicht belehrt, / Verlassend sich auf eigene Kunst, / Daß sie erlangen Ruhm und Gunst.') $)^{8}$ What started out as a criticism of foolish behavior is now turned into an accusation of heresy with 'Eygenrichtikeit' considered its cause, which - though the goal may be achieving fame - is ultimately rooted in the inability to listen to others and to follow recognized authorities. The subsequent passage lists examples from the Old Testament regarding the validity of the thesis of dangerous pertinacity presented in the exordium. Once again, reference is made to fools who have missed their way and are climbing after birds' nests, fools who want to climb trees without the support of ladders and, consequently, fall down. Biblical figures like Noah and Korah are mentioned. By contrast, the central image in chapter 36 is that of the 'seamless robe of Christ', which we should not dare to divide. Heretics, by contrast, strive to fragment the Church.

The passage immediately following states that 'foolhardiness has misled many a ship' ('Vermessenheit viel Schiff verführt'), an allusion to the end of the chapter where we read about Odysseus, who managed to escape the song of the seductive Sirens only by plugging his ears with wax. Here the song of the Sirens is equated with the false teachings of the heretics. ${ }^{9}$

\footnotetext{
${ }_{8}^{7}$ Ibidem.

Brant, Narrenschiff 38 .

What Uhoever hopes to leave the ship of fools, / Has to stop up his ears with wax, / That's

them lysses did on the ocean / When he saw the multitude of Sirens / And escaped from

¿4 weich through his wisdom / Which ended their pride'. ('Wer hofft vom Narrenschiff , / Muß in die Ohren Wachs sich streichen, / Das tat Ulysses auf dem Meer, /
} 
With the image of heretic Sirens, Brant in the Ship of Fools continues an older tradition of representing heresy that reaches back to the Physiologus, where we find this statement: 'For they [viz., the heretics], like the Sirens, seduce innocent hearts with their sweet words and impressive speech'. ('Denn durch ihre süßen Reden und prächtigen Worte verführen sie wie die Sirenen die unschuldigen Herzen'.) Hugo Rahner explored this relationship in great depth, presenting numerous examples of the use of the Siren metaphor by the Church Fathers in his study Griechische Mythen in christlicher Deutung. ${ }^{10}$

One of my reasons for presenting this brief summary of Brant's chapter on 'Eygenrichtikeit' is that it is a popular source in which heresy is associated with the unusual image of robbing a nest. There is an explicit mention of heretics, which means that Brant, by implication, is identifying with the orthodoxy of the Roman Church. It is well known that the Strasbourg humanist worked to a great extent with intratextual references in the Ship of Fools: the impending Last Judgment, to be accompanied by numerous false teachings, is of course mentioned in the context of heresy. Chapter 98, after imputing folly to Saracens, Turks, and pagans, continues thus [Fig. 4]: 'Furthermore, there is the school of heretics, / In Prague on their seat of fools / Which has spread so far, / That it now also includes Moravia'. ('Dazu kommt noch die Ketzerschul', / In Prag auf ihrem Narrenstuhl, / Die so verbreitet ihren Stand, / Daß sie jetzt hat auch Mährenland'. . ${ }^{11}$ No doubt, Brant is alluding to the Hussites at the University of Prague, whose teachings after 1453 had spread into Moravia as well. Again and again, he speaks of the heresies of the Last Days, stating in chapter 99, "About the Decline of Faith", that hand in hand with the demise of the Holy Roman Empire goes the decline of the 'Christian faith', which is being diminished daily by the multitude of heretics. ${ }^{12}$

Finally, in Chapter 103, which is devoted to the Antichrist, Brant turns his attention to those fools who take it upon themselves to 'distort' and bend' Holy Scripture. As we have seen, the description of and reference to foolish religious heresies is an important motif in the Ship of Fools. In Als er sah der Sirenen Heer / Und ihm durch Weisheit nur entkam, / Womit ihr Stolz ein
Ende nahm'.)

10 Rahner $\mathrm{H}_{.}$Griechische Mythen in christlicher Deutung (Darmstadt: 1966) 281-292. On 10 Rahner H., Griechische Mythen in christlicher Deutung (Darmstadt: 1966) $281-29$ hristli-
the topical iconography of heretical teaching, see Müller J., "Von der Odyssee eines chroford
chen Gelehrten - Eine neue Interpretation von Hans Holbeins Erasmusbildnis in Longfor

chen Gelehrten - Eine neue Interpretation von Hans Holbeins Erasmusbildnis $179^{-211}$.
Castle", Zeitschrift des deutschen Vereins für Kunstwissenschaft 49/50 (1995/96) $179^{11}$ Brant, Narrenschiff 93 .

12 Ibidem 94. 


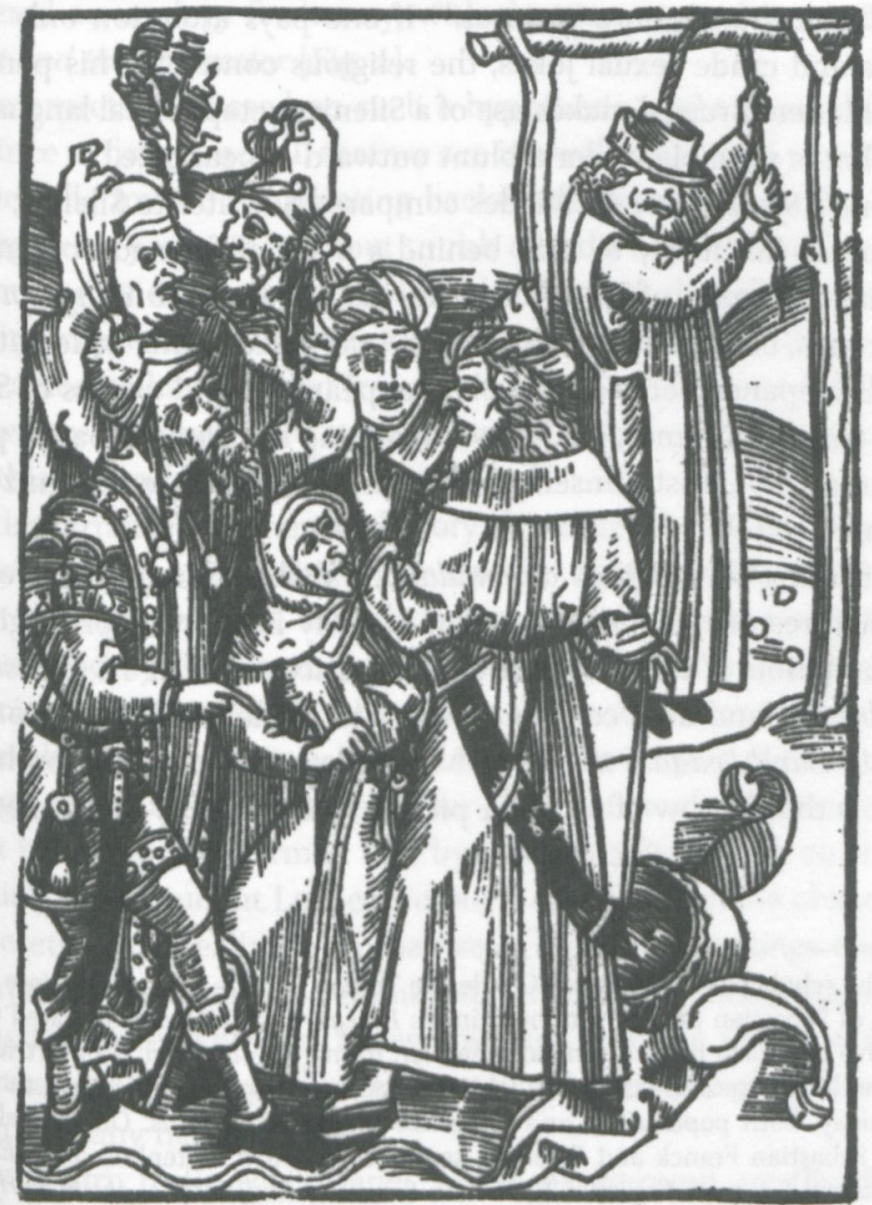

Fig. 4. "Chapter 98: Von vslendigen narren". Woodcut illustration to Sebastian Brant, Ship of Fools (Basel, Johann Bergmann von Olpe: 1494).

this context, 'Eygenrichtikeit' is the intellectual vice that causes people to stray from the right path and become heretics.

\section{The Subversive Picture}

The following interpretation of the above-mentioned pictures by Bruegel
is associated with the thesis that the genre painting typical of this Flemish
painter is a platform for critical argumentation. The painter is conceal-
ing his anti-confessional spiritualistic statements in the crassness of his 
peasant satires and genre pictures. ${ }^{13}$ If one pays attention only to bare buttocks and crude sexual jokes, the religious content of his panels will remain hidden. Bruegel makes use of a Silenic metaphorical language that hides what is valuable under a blunt outward appearance. ${ }^{14}$

In Plato's Symposium Alcibiades compared Socrates to Silenus, thereby emphasizing his ability to hide behind a mask of feigned obscenity and simplicity. Erasmus of Rotterdam devoted a separate adagium to the Silenic topos, but Marsilio Ficino in De Amore had earlier called attention to the discrepancy between the plain appearance and origins of Socrates and his true importance, as if he were talking not about a pagan philos $0^{-}$ pher, but about Christ himself whom many had failed to recognize as the Messiah. ${ }^{15}$

In reflecting on religious dissimulatio, I shall focus on the two Silenic genre pictures of 1568 , mentioned above. My interpretation begins with an examination of the heretical content discernible in The Peasant and the Birdnester, and then continues with a more detailed discussion of The Fall of the Blind Leading the Blind. ${ }^{16}$ One reason for dwelling on heretical content is that I know of no other picture in the history of art that can be

13 In the scholarship on Bruegel, Charles de Tolnay was the first to associate him with the ideas of Sebastian Franck. Stridbeck in his Bruegel Studies later elaborated upon this interpretive approach in an exemplary manner. In my own research, I have tried further to explore these issues. Sebastian Franck, a thinker very popular in his time, though little known today, both popularized and radicalized ideas of Erasmus. On the relationship with a Radical Erasmus: Erasmus' Work as a Source of Radical Thought in Early Mothos Europe (Toronto: 2009) 13-31, 69-93; and Müller J., “'Pieter der Drollige' oder der My dtere: vom Bauern-Bruegel", in Ertz K. (ed.), Pieter Breughel der Jüngere, Jan Brueghel der All $\mathrm{us}^{\mathrm{s}}$ flämische Malerei um 1600 (Lingen: 1997) 42-53; Müller J., "Überlegungen zum Realisnes", Pieter Bruegels d.Ä. am Beispiel seiner Darstellung des Bethlehemitischen Kindermor ${ }^{2} 9^{6 ;}$ Morgen-Glantz: Zeitschrift der Christian Knorr von Rosenroth-Gesellschaft 8 (1998) $273^{-2}$ hand idem, "Bild und Zeit. Überlegungen zur Zeitgestalt in Pieter Bruegels "Bauernhoch zeitsmahl' ", in Pochat G. (ed.), Erzählte Zeit und Gedächtnis: narrative Strukturen und Problem der Sinnstiftung im Denkmal (Graz: 2005) 72-81.

14 On this Erasmian mode of metaphorical usage, see Lupi W.F., "La scuola dei Silen ni", Festschrift für Eugenio Garin (Pisa: 1987) 1-20; Müller W.G., "Das Problem von Schein und io Garin (Pisa: 1987) 1-20; Müller W.G., "Das Problem von Scher Renais"
sileni Alcibiadis' und Shakespeares 'Macbeth'", Wolfenbütteler Renglish
5 (1991) 1-18; and Müller, Das Paradox als Bildform 90-117. An Eng" of sance-Mitteilungen 15 (1991) 1-18; and Müller, Das Paradox translation of the Silenus adagium can be found in Mann Philipps M., The "Adag is by Erasmus. A study with Translations (Cambridge: 1964) 269-296. The best commentary liticl Silvana Seidel Menchi, cf. Seidel Menchi S., Erasmo da Rotterdam: Adagia. Sei saggi po in forma di proverbi, a cura di Silvana Seidel Menchi (Turin: 1980) 60-119.

in forma di proverbi, a cura di Silvana Seidel Menchi (Turin: 1980) 6o-119.
15 Ficinus M., Über die Liebe oder Platons Gastmahl, eds. P.R. Blum - K.P. Hasse (Ham-
burg: 1984) 311-317.

16 Müller, "Ein anderer Laokoon" 389-455. 
considered an apology for heresy, with the exception of Pieter Bruegel's Peasant and the Birdnester [Fig. 2].

An interpretation based on such a hypothesis might seem absurd initially, since at first glance all that we see is a well-nourished peasant walking cheerfully toward us, pointing backwards over his shoulder. ${ }^{17}$ There we recognize a young man about to rob a bird's nest. He has hooked his legs firmly around the tree trunk in order to reach directly into the nest. His falling cap is an indication that this activity is not entirely without danger, since he has no hand free to catch it. Based on our discussion of Brant, we are now prepared to discover the image of a pertinacious heretic in this nest robber.

The importance of Brant's allegory for Bruegel has not been sufficiently emphasized for a simple reason: the Flemish edition of the Ship of Fools, dating from 1548, though it does contain the image of the nest robber, drastically changes the explanatory text. ${ }^{18}$ It no longer rails against Pertinacious heretics; rather, the chapter, in warning the reader not to abandon the true path, entirely circumvents the subject of false religious teachings. There is a simple reason for this change: the Antwerp edition was not based on the German text by Sebastian Brant, but on the Latin translation of his student Locher. To put it another way, the chapter critical of heretics and dealing with the rise of heretical teachings during the Last Days, was reduced to a humanistic allegory of moderation. In my Opinion, it is quite likely that Bruegel worked with the 1497 Low German edition that contains Brant's complete text and accordingly refers to 'vele Ketter(n)' ('many heretics').19

Let us return to Bruegel's panel. In the background, on the right, we see a farmhouse with a thatched roof. A horse is just being led into the arn, and the farm appears downright friendly in the noonday sun. In this part of the picture, the landscape appears flat and accessible, whereas

${ }^{17}$ Müller, Das Paradox als Bildform 82-89. Todd Richardson, in his dissertation and see Rich book, largely downplays the theological issues, focussing instead on formal issues; lands ( 18 (Farnham: 2011) 149-159.

The Ethan Matt Kavaler, in his interpretation of the beekeeper drawing and the panel

unaware of and the Birdnester, brings up the issue of the apt proverbial sense, but seems
Pieter Brumbivalence to be discovered in the birdnester image; see Kavaler E.M.,

${ }_{19}$ Bruegel: Parables of Order and Enterprise (Cambridge: 1999) 248-254.

edition. Brant S., Dat narren schyp, ed. T. Sodmann (Bremen: 1980) n.p. The Low German

is the however, shows the heretic standing in front of the tree. Key to my interpretation

Ply lookinection between word and image, since I assume that Bruegel, rather than simking for a formal motvie, intended the birdnester to stand for the heretic. 
it is barred on the opposite side by tree trunks. The artist has skillfully directed our perception of the picture - before we are even aware what it is all about, our eye is drawn to the pointing gesture of the cowherd, who has a drinking horn hanging from his belt and is carrying a stick. On the ground to his right is a bag, probably left there by the nest robber. It may be intended to transport the eggs stolen from the nest. The thief, having left the bag on the ground, betrays his presence and intentions. After looking at the picture for a while, however, it becomes apparent that the cowherd is about to fall headlong into a ditch. He would have done better to apply his wisdom to himself, instead of pointing back at the nest robber who appears capable of hanging on to the tree.

In order to get closer to the iconography of the picture, we need to use additional examples as comparanda. In Brant's Ship of Fools there is not only a model for the birdnester, but also for the peasant. In chapter 21 we encounter a fool who wants to show others the way, though he himself is in a puddle [Fig. 5]. ${ }^{20}$ Brant accuses such fools of malice, since they are ready to slander everyone, yet unable to perceive the beam in their own eye. The illustration portrays this hypocritical behavior by showing how the fool stands in a puddle and yet points at a shrine that features Christ on the cross.

Another work of art should be mentioned here. The Kupferstichkabinett in Berlin possesses a drawing by Bruegel that likewise depicts a thief robbing a nest; strangely, instead of a cowherd we see beekeepers col- $^{-}$ lecting honey from their hives [Fig. 6]. The beehive has often been interpreted as an allegory of the Catholic Church, by reference to a critical reformatory text, Philips Marnix van Sint-Aldegonde's, De bijencorf der H. Roomschen Kercke, which was, however, not published until $1569 .^{21}$ Along the lower edge of the drawing, there is a Flemish proverb which has long served as a key for interpreting both the drawing and the panel. It reads: 'He who knows where the nest is, has the knowledge; he who robs it, has the nest'. No doubt, this elevates the importance of action,

20 Milla-Villena R., "Deux Moralités de Pierre Bruegel l'Ancien à l'Époque de la Mon' tée du Calvinisme aux Pays-Bas", La littérature populaire aux XV'me et XVI ème Siècles. Ac la du deuxième Colloque de Goutelas. Bulletin de l'Association d'études sur L'Humanism 83.
Réforme et la Renaissance (n. p.: 1979) 188-195; and Müller, Das Paradox als Bildform

21 Cf. Sybesma J., "The Reception of Bruegel's 'Beekeepers'. A Matter of Choice", The and Bulletin 73, 3 (1991) 467-478; and Noll T., "Pieter Bruegel d.Ä. Der Bauer, der Vogeldie, in my


Mielke H., Pieter Bruegel. Die Zeichnungen (Turnhout: 1997) 68-69. 




Fig. 5. "Chapter 21: Von stroffen vnd selb tun". Woodcut illustration to Sebastian Brant, Ship of Fools (Basel, Johann Bergmann von Olpe: 1494).

the deed, over mere thought. But in fact, this piece of proverbial wisdom seems well matched neither for the drawing or the panel. In the nest robber, Brant sketches an allegory of the heretic whose pertinacity is so great that he loses his way climbing the tree and presumes to look for paths where there are none. At the end of his text, the Strasbourg humanist laments the fact that heretics have the audacity to divide the robe of Christ. In the Ship of Fools he opposes these sectarians who challenge the unity of the Catholic Church. What is interesting here is the isotopy of his text, which is the starting point for Bruegel's iconographic
topy 


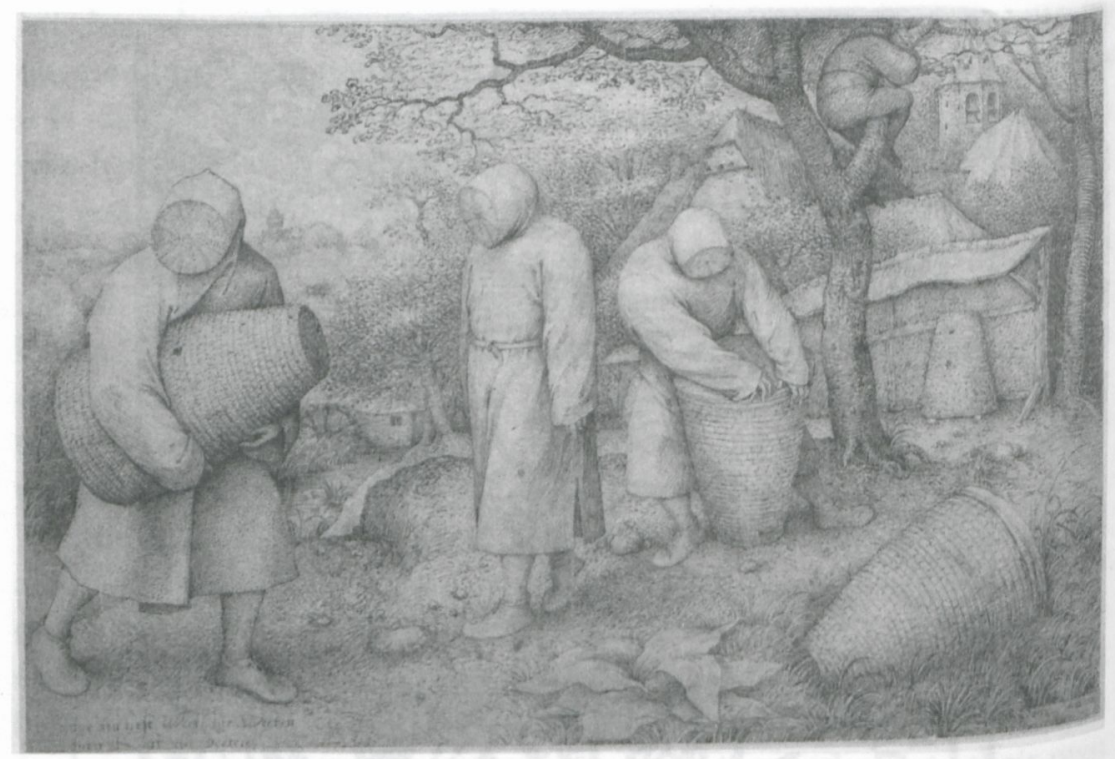

Fig. 6. Pieter Bruegel the Elder, The Beekeepers (ca. 1568). Pen and ink, $20.3^{\times}$ $30.9 \mathrm{~cm}$. Berlin, Staatliche Museen, Kupferstichkabinett.

design. It deals with a fool who leaves the right and level road and gets lost in the wilderness, searching for bird nests along paths that block his way forward. Bruegel's painted image starts from this literary description; however, he turns Brant's supposed wisdom on its head. Initially, the dramatic narrative of his picture seduces us into agreeing with Brant, $\mathrm{co}^{\mathrm{n}^{-}}$ sidering the cowherd to be wise, while believing the nestrobber to be in danger - until we come to realize that the exact opposite is the case. The seemingly flat and harmless path on the right is crisscrossed by canals. To climb the trees may seem at first the more difficult course of action, but ultimately, it turns out to be the less dangerous option. Indeed, in the final analysis the heretic turns out to be the wise one who, in contrast to the peasant, will be spared a bad fall. Another significant pictorial detail, the water lily placed on the same vertical axis as the nest robber, shall concern us presently.

Let me summarize: Bruegel would seem to be formulating an iro nic $^{\text {ic }}$ statement aimed at reversal. The supposedly wise turn out to be patently foolish, whereas the fools prove to be prudent. Cleverly, the artist $\mathrm{suc}^{-}$ ceeds in updating a famous concept, since he adapts the metaphor of the two paths through life. The path of vice starts out wide and appears free 
of danger, whereas the path of virtue is arduous and difficult to follow. ${ }^{22}$ The artist succeeds in creating a clever iconographic program insofar as he manages implicitly to defend heresy, associating it with the characterisitics of the virtuous path, even while dissimulating this message. Yet another comparandum needs to be explored further in this context - an additional motif that serves to criticize Roman Catholicism: our cowherd actually originates in Michelangelo's Sistine Chapel. ${ }^{23}$ It is surely no accident that the artist, in borrowing this motif alludes metonymically to the key work of Catholic orthodoxy. And at that, it is quite funny to see a noble and fearless figure transformed into a clumsy peasant. ${ }^{24}$

As early as the 1560 s Bruegel traveled to Italy with the geographer Abraham Ortelius and was, presumably, able to study this fresco in the original. ${ }^{25}$ But numerous motifs would have also been accessible in the form of reproductive prints [Fig. 7]. As first observed by Stridbeck, the artist based his cowherd on a so-called spiritello by Michelangelo [Fig. $\left.{ }^{8}\right]{ }^{26}$ It is important to note here that the boy in the fresco points behind himself toward the prophets and sibyls. He advances fearlessly, striding foward. Although he stands on a narrow console whence his next step will lead into the abyss, he is not afraid and puts his trust in God. In the Sistine Chapel, Michelangelo plays incessantly with an architecture that is impossible from a static point of view, staging both how the figures fall and are held back from the precipice. To the viewer of the fresco, Michelangelo is suggesting this conclusion: just as God's grace supports all humankind while remaining inscrutable, so too, the decisions of the Pope regarding

\footnotetext{
${ }^{22}$ On the two paths, see Harms W., Homo viator in bivio. Studien zur Bildlichkeit des ges (Munich: 1970).

referene owe this discovery to Carl Gustav Stridbeck, although his claim, based on this be ence, that Michelangelo served as a primary model for Pieter Bruegel the Elder, must

Florentically contradicted. Quite the contrary, Bruegel here parodizes the style of the

24

program my opinion, the Michelangelo motif is also a metonymical hint at the iconographic

On the of the papal chapel, in which the hegemony of the Catholic Church is expressed.

Sixtinischen meaning of the Sistine Chapel, see Pfeiffer H., "Gemalte Theologie in der

Archivum Kapelle. Die Fresken des Michelangelo Buonarotti ausgeführt unter Julius II",

(Londom historiae pontificiae 31 (1993) 69-107; King R., Michelangelo and the pope's ceiling

nel Maus: 2002); and Accomando Gandini M., Relazioni e confronti negli affreschi sistini e

${ }_{25}$ Kausoleo di Giulio II (Ascoli Piceno: 2004). ${ }_{26}^{2}{ }_{212}$ Kaschek B., Weltzeit und Endzeit. Die 'Monatsbilder' Pieter Bruegels d. A. (Munich:

in Print: $\mathrm{On}$ the reception of Michelangelo in the graphic arts, see Barnes B.A., Michelangelo rint: Reproductions as Response in the Sixteenth Century (Farnham: 2010).
} 


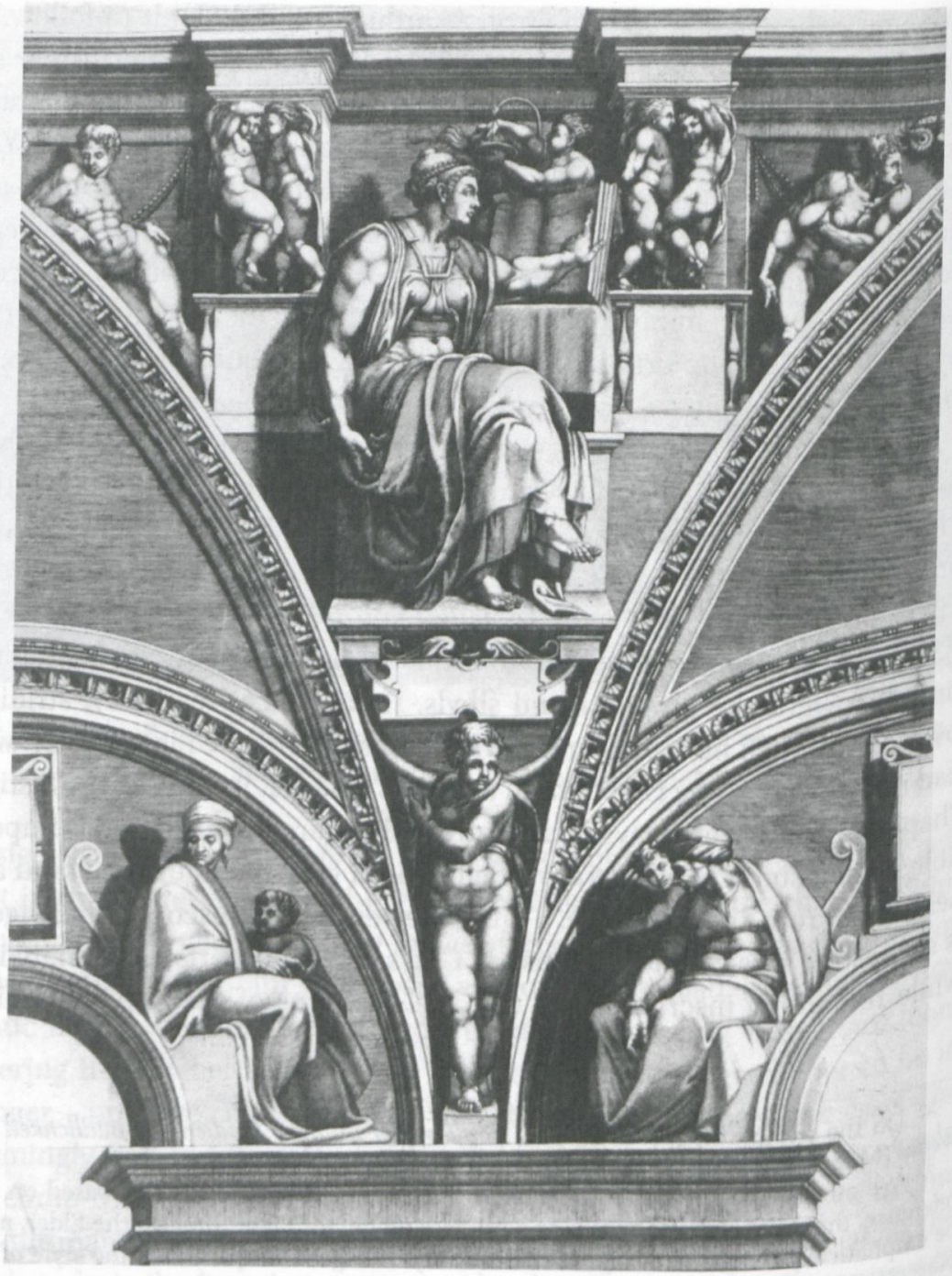

Fig. 7. Giorgio Ghisi, after Michelangelo, Spandrel of the Sistine Chapel: Erithrean Sibyl (ca. 1570-1575). Engraving, $56.9 \times 43.3 \mathrm{~cm}$. London, British Museum, Department of Prints and Drawings.

the Catholic faithful are inscrutable. Obviously, Bruegel is contradicting this papist world view and ridiculing the supposed superiority of institutional Catholicism and its theology. He does this by selecting a $\mathrm{qu}^{\mathrm{u}} \mathrm{O}^{-}$ tation that is not immediately recognizable, since he is utilizing a marginal motif that - compared to the famous renderings of the prophets and sibylswould not have been readily identifiable. Bruegel has designed a clever 


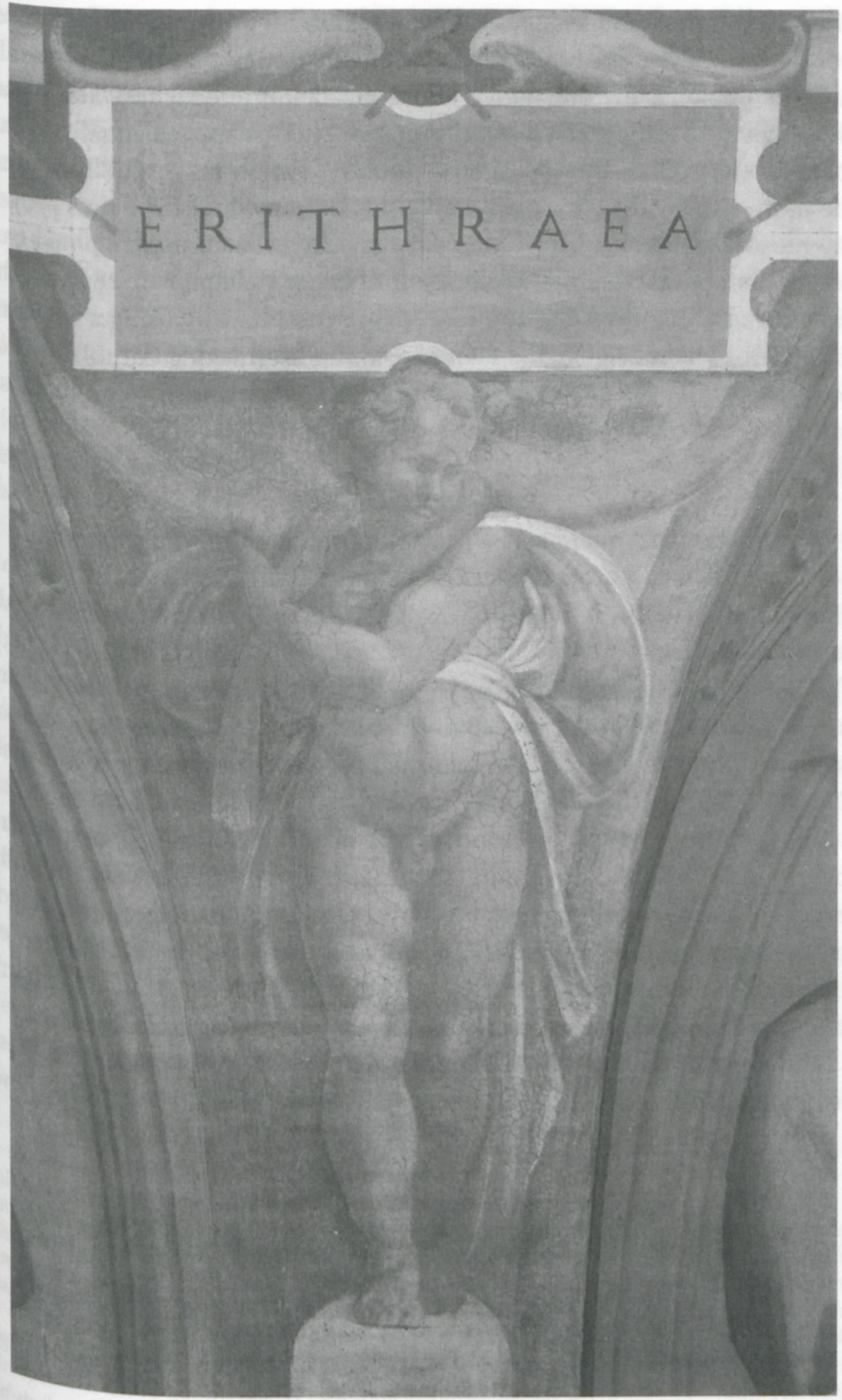

Fig. 8. Michelangelo, Putto beneath the Erithrean Sibyl. Fresco. Vatican City, Sistine Chapel. 
pictorial program. He seduces the viewer into identifying with the superior gesture of the cowherd. When we finally notice that the supposedly superior person is the one who is about to fall, it is already too late. We as viewers have been deprived of our superiority. This applies equally to the scene of the action. Instead of tree climbing, which may initially appear the more risky endeavor, it is actually the swampy landscape that proves the most treacherous. I have thus far suggested that Bruegel's panel can be understood as a subtle exploration of Brant's chapter on 'Eygenrichtikeit'. And going even further, I have suggested that by using a motif in the style of Michelangelo, the Flemish painter is attacking Catholic orthodoxy. Now what of The Fall of the Blind Leading the Blind? Does it likewise comment critically on the Church?

Traditional Interpretations of The Fall of the Blind Leading the Blind

There are few works by Pieter Bruegel the Elder that art historians have admired so unanimously as The Fall of the Blind Leading the Blind [Fig. 3]. The painting is signed and bears the date 1568 . It measures $86 \times 154 \mathrm{~cm}$. and is now housed in the Museo di Capodimonte in Naples. ${ }^{27}$ It is one of only two works by the artist not painted on wood; rather, it is a so-called Tüchlein painting that uses glue as a binding medium for the paint. ${ }^{28}$

The painting depicts a group of six blind men walking across the foreground of the picture from left to right. The picture is very skillfully arranged: the forward progression is aligned along the descending diagonal that connects the upper left corner with the lower right. This creates the impression that the men are joined together like the links in a chain, an impression that has been emphasized by all interpreters alike. ${ }^{29}$

The topic of the fall of the blind is mentioned three times in the $\mathrm{Ne}^{\mathrm{w}}$ Testament. In the Gospel of Matthew 15:14, Jesus calls the Pharisees blind

27 During his time in Flanders as secretary of Allessandro Farnese, the Florentine noble man Cosimo Masi managed to collect some important paintings, including The Fall of the Blind Leading the Blind and the so-called Misanthrope. Both pictures were exprop Glant2 and became the property of the Farnese family, on which see Vitali C. (ed.), Der Kunst und Sammelleidenschaft in der Renaissance [exh. cat., Haus der München] (Munich: 1995) 265-66.

28 On Tüchlein painting in general, see Bosshard E.D., "Tüchleinmalerei - eine billige Ersatztechnik?", Zeitschrift für Kunstgeschichte 45 (1982) 31-42.

29 Max Imdahl gives a powerful formal description of the inevitable fall, although he ${ }^{29}$ Max Imdahl gives a powerful formal description of the inevitable fall, althoug $g^{r a}$
sets little store in the iconographic details; see Imdahl M., Giotto. Arenafresken: Ikonog
phie, Ikonologie, Ikonik (Munich: 1988) 99-110. 
leaders of the blind', who lead the people astray so that both fall into the pit. In Luke 6:39-41, Jesus asks the rhetorical question whether a blind man can lead another blind man without both of them falling into a pit. And finally, the apostle Paul picks up the image of the blind guide in his Letter to the Romans 2:19, to make clear that the knowledge of God's commandments alone is not sufficient for gaining salvation.

Although the painting has been handed down in ruinous condition, it has been uniformly praised. Wolfgang Stechow calls it an 'absolute masterpiece', ${ }^{30}$ as also does Carl Gustaf Stridbeck, who rates it a 'masterpiece' in the very first sentence of his study. ${ }^{31}$ Fritz Grossmann considers it the ultima ratio of the painter's creativity, stating that Bruegel in this picture reached the pinnacle of expression. ${ }^{32}$ Similarly, Roger H. Marijnissen concurs with these assessments, praising The Fall of the Blind Leading the Blind as the painter's most touching work. ${ }^{33}$

Two positions may be differentiated in an attempt at a rough classification of the interpretations of Bruegel's Fall of the Blind Leading the Blind. Hans Sedlmayr saw the blind men ('Verblendete') as representatives of the Synagogue, in opposition to the Church in the background. ${ }^{34}$ In contrast, Carl Gustaf Stridbeck emphasized the anti-clerical tendency of the picture and assigned a negative interpretation to the Church. Just as Jesus directed his parables against the Pharisees, Bruegel is criticizing the institution of the Church and its priests. In this context, he points to a passage from Sebastian Franck's Die Güldin Arch, in which priests are referred to as guides of the blind. ${ }^{35}$

But how well known, in general, should we consider the German theologian? In the Netherlands around the middle of the sixteenth century, Franck was a noted author whose writings had a far-reaching influence. Senteen of his works were translated into Dutch between $155^{8}$ and 1621 , followed by several reprints. ${ }^{36}$ Also, from the very beginning he was perceived as a critic of the churches and confessions, whose true and legitimate

31 Stechow W., Bruegel, trans. H. Frank (Cologne: 1974) 134.

${ }_{\text {Pieter }}{ }^{31}$ Stridbeck C.G., Bruegelstudien. Untersuchungen zu den ikonologischen Problemen bei

holm: Bruegel d. A. sowie dessen Beziehungen zum niederländischen Romanismus (Stock-

32 1956) 259.

33 Grossmann F., Pieter Bruegel. Gesamtausgabe der Gemälde (Herrsching: 1973) 203.

${ }^{34}$ Marijnissen R.H. - Seidel M., Bruegel (New York: 1984) 368.
Bruans Sedlmayr developed interpretation in great depth; see Sedlmayr H., "Pieter

schen Seminar Dturz der Blinden. Paradigma einer Strukturanalyse", Hefte des Kunsthistori-

${ }^{35}$ Stridinars der Universität München 2 (1957) 1-49.

${ }_{36}$ Stridbeck, Bruegelstudien 262.

Weigelt H., Sebastian Franck und die lutherische Reformation (Gütersloh: 1972) 68. 
influence, according to Franck, could only be exerted internally, indeed in secret. His criticism of the official churches targets their secularization, no confession excepted. For him, God can only be experienced internally and has no need for mediation through priests and sacraments. He contests external authority of any kind. Even the Bible is not an end in itself for him; consequently, he rejects Luther's concept of sola scriptura, embracing the Holy Scriptures instead as a tool and possible gateway to a greater spirituality. ${ }^{37}$

My attempt at a critical interpretation of the picture following Stridbeck automatically raises the question of Bruegel's religious convictions. Would he not - in accordance with such a heretical approach - criticize each and every confessional manifestation of Christianity as heresy? There is no consensus among scholars regarding the confessional identity of the painter. Generally, the problem is either avoided or declared not answerable. There are only a few interpreters who have taken a clear stand, among them, in the past, Karl Tolnai and, following him, Carl Gustaf Stridbeck who attempted to draw upon Franck's writings time and again in his Bruegelstudien. ${ }^{38}$

Anyone who connects Bruegel with Franck's ideas needs to take into account the status of the latter as a heretic and the difficulties that might have arisen for the artist, as a result. ${ }^{39}$ As regards Bruegel, David Freedberg has reminded us of the problem of Nicodemism, construed as a religious practice critical of organized religion and its denominations. Nicodemism, as it is generally understood, means the merely pretended affiliation with

37 On Sebastian Franck, see Wollgast S., Beiträge zum 500. Geburtstag von Sebastian 37 On Sebastian Franck, see Wollgast S., Beiträge zum 50o. Geburtstag von Sebasteen
Franck (1499-1542) (Berlin: 1999); and Dejung C., Sebastian Franck interkulturell gelesen
(Nordhausen: 2005).

38 Indeed, there are great theoretical affinities between Erasmus and Franck. For Erasmus, already, the essence of the Christian religion is lost, if one chooses to perceive it as the sum of its rites and conventions. He expressly rejects the veneration of the $\mathrm{Vir}^{-}$ gin Mary, pilgrimages, the concept of real presence in the Eucharist, just to name a ${ }^{\mathrm{w}}$ points of criticism he formulated against Catholic rites and rituals. It is not without reas $\mathrm{O}^{\text {n }}$ that numerous writings of the Rotterdam scholar were put on the List of Prohibited Bo during the sixteenth century. In retrospect, it appears an irony of history that Sebastian Franck listed the Dutch theologian in his Ketzerchronik among the important heretics and hence the true Christians, a fact that is said to have infuriated the latter, leading tim to intervene with the Strasbourg City Council in requesting Franck's banishment. Evere though Franck owed many of his convictions to the Rotterdam scholar, he was much God to radical as regards their consequences and turned openly against all confessions. ${ }^{2}$ from him was not a privilege; rather, God was accessible to all mankind and all religions I Eraswithin. On this aspect of Franck's theology, see Bietenholz, Encounters with a Radical bras mus 13-31, 69-93.

39 Charles de Tolnay and Carl Gustav Stridbeck disregarded this issue. 
an official church during the time of the Reformation..$^{40}$ A person would feign a confessional identity, but adhere to another conviction in secret.

In scholarly studies, Freedberg's assumption has played a minor role, at best. This is partly due to the fact that his research hypothesis leads to few if any convincing interpretations. In his essay, he does not explain what kind of religious convictions Bruegel needed to hide or in what way this manifested itself in his works. Be that as it may, this does not change the fact that the issue of Nicodemism appears to have been of some importance in the Netherlands of the 1560 s.

Sebastian Franck had been dead for more than twenty years when The Fall of the Blind Leading the Blind was created. It would be amiss, however, to conclude that he was therefore unknown. Indeed, the Dutch Anabaptist Dirk Philips authored a polemical paper against the German theologian in the mid-156os. Two letters dating from the thirties and forties of the sixteenth century, written by Franck to heretics who were friends, had been translated into Dutch shortly before and summarized in a small publication. This prompted polemics by Philips lamenting the success of the German theologian. He claimed the reason for Franck's large number of 'followers, readers, and students' was that he advocated a Nicodemic strategy.41 Hiding one's own Christian convictions was considered hypocrisy by the Anabaptist Philips. He stated that practicing 'false worship' was unacceptable under any circumstances, that it was not only wrong but the 'root of idolatry'. ${ }^{2}$ The anger of the Dutch Anabaptist is understandable since Franck had written in one of the letters that it was acceptable even for those who held different convictions to participate in the Mass and rites of Catholics. ${ }^{43}$

${ }^{40}$ Freedberg D., "The Life of Pieter Bruegel the Elder", in idem (ed.), The Prints of Pieter tion, the Elder [exh. cat., Bridgeston Museum of Art, Tokyo] (Tokyo: 1989) 21-31. In addi-

a Forgotten, "Allusion and Topicality in the Work of Pieter Bruegel: The Implications of

Regatten Polemic", in ibidem $53-65$.

tion, Pering issues of Nicodemism in general, see Zagorin P., Ways of lying: DissimulaM.G.K r. demieten Verschooninghe van de roomsche afgoderye'. De polemiek van Calvijn met nico-

41 in het bijzonder met Coornhert (Houten: 2001).

1544, "Excuse likewise complained about the Nicodemites in a polemical text published in

Studiencuse a Messieurs les Nicodemites", for which see Busch E. - Heron A. et al., Calvin-

${ }_{2}^{42}$ Fausgabe, Vol. 3. Reformatorische Kontroversen (Neukirchen-Vluyn: 1999) 222-265.

listen, Schw. (ed.), Der linke Flügel der Reformation. Glaubenszeugnisse der Täufer, Spiritua-

43. Schwärmer und Antitrinitarier (Bremen: 1962) 181.

der Mystik Latin letter by Sebastian Franck is included in Hegler A., Beiträge zur Geschichte Mystik in der Reformationszeit, ed. W. Köhler (Berlin: 1906) 88-90, esp. 99. 
Continuing now with a close reading of Bruegel's Fall of the Blind Leading the Blind, let me state at the outset that I intend to treat the picture as subversive. This wording may sound more fashionable than intended. By subversion as regards pictures of the early modern period I mean three things: first, the ability to encode a controversial theological issue in a presumably secular genre painting, in other words, in a supposedly everyday scene. Secondly, the subversive nature of the picture may pertain to the presence of heterodox content in a supposedly orthodox topic, so that content critical of religion is concealed in a conventional apparency. Thirdly, subversion involves the issue of religious dissimulatio. The artist has to succeed in hiding the clavis interpretandi of his work. Put differently, this kind of subversive treatment of a painting facilitates communication of critical theological content. Framed in terms of pathos, it is the function of this kind of art to support religious pertinacity. ${ }^{44}$ It goes without saying that such a picture was intended for persons holding the same convictions, who would have been able to discern the religious clues embedded therein. Though we know that Bruegel socialized with the cultural elite of Antwerp and Brussels, there is no information about who commissioned these paintings and in what circumstances, but it is likely that they were commissioned rather than painted for the open market. ${ }^{45}$

My question, then, is this: What exactly does a heretical picture look like? How can messages that would be called religiously deviant be communicated in and through pictures? What kind of techniques need to be employed to encode such a pictorial content and to reveal it to likeminded persons?

\section{Genre or History?}

Six blind men have banded together to go begging. ${ }^{46}$ Presumably the group is on its way to church to play music for the worshipers entering and leaving the building. This much is certain: they missed the road in the

44 Cf. Schwerhoff G., "Gottlosigkeit und Eigensinn. Religiöse Devianz in der Frihen Neuzeit", in Vorländer H. (ed.), Transzendenz und Gemeinsinn. Themen und Perspektiven

45 The most precise observations regarding Bruegel's environment appear in Kasc Weltzeit und Endzeit 39-107.

46 On the representation of beggars in the sixteenth century, see Nichols T., The Art of Poverty: Irony and Ideal in Sixteenth-Century Beggar Imagery (Manchester: 2007). 


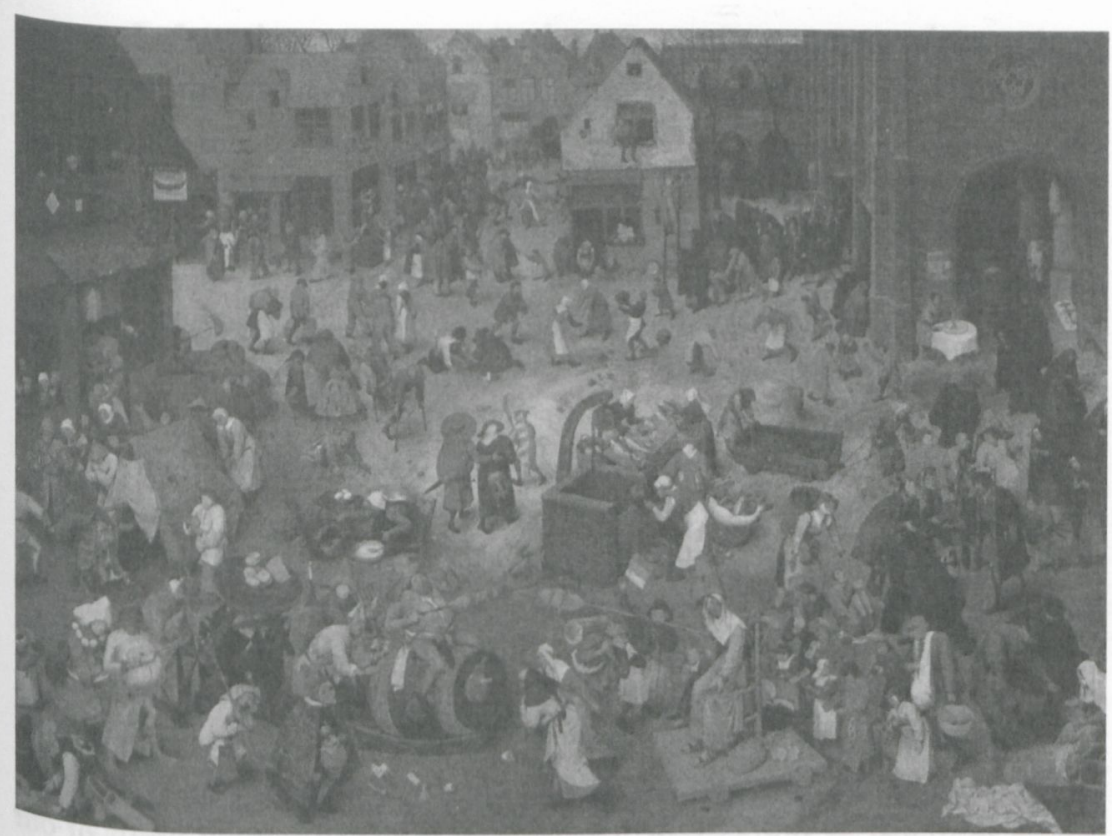

Fig. 9. Pieter Bruegel the Elder, Fight between Carnival and Lent (1559). Oil on panel, $118 \times 164.5 \mathrm{~cm}$. Vienna, Kunsthistorisches Museum.

middle of the picture leading to the church and, as a result, ended up on rough terrain. Part of the group would have played music while the rest of them were begging. A hurdy-gurdy is plainly visible and about to be submerged in water together with the leader. The blind man at the end of the row appears as well to be carrying an instrument beneath his wide cloak, while the third beggar has a plate hanging from his belt that might be intended for collecting alms. We get a somewhat better mental image of such a scene by taking a look at Bruegel's panel The Fight Between Carnival and Lent [Fig. 9]. At the door of the church, a group of beggars is waiting for the Mass to end and the rich patricians to come out. Among these pitiful creatures is a blind beggar, whose eyes have been gouged out, with a black and white guide dog at his feet. He is holding out his cap as the man in front of him prepares to put in a pittance.

The accident of the fall of the blind happens in a flat Brabantine landscape. But the awareness of the place of action dawns only gradually on the viewer, so completely are his eyes riveted by the inevitable fall of the men. In the right half of the painting, the late medieval church building identified with the church of Sint Anna Pede near Brussels catches 
the eye. ${ }^{47}$ The church tower reaches to the upper edge of the picture. On account of its height, if nothing else, this late medieval building marks the center of the village with its houses, gables, and roofs recognizable behind the blind man on the left. Along the horizon on the right, there are more buildings including a palace or a castle. Although the church building may have been modeled after Sint Anna Pede, the hill in the background is Bruegel's invention. So what you see is by no means a direct representation of an existing landscape; rather, it is a picture that was enhanced using elements of reality.

While most objects in the background are shown overlapping and blocked, the church is clearly recognizable to the viewer. Furthermore, it is emphasized through the dramaturgy of the painting by its placement on the 'decision axis' of the action: we wonder if the third blind beggar from the right will let go just in time, or if he will end up in the water with the one about to fall and the one who has already fallen. The staging of this dramatic moment is accompanied by a clever manipulation of the viewer's eye, since our point of sight is not in the center of the picture, but at the level of the church. The church is the vanishing point of our field of vision.

Like other late Bruegel works, this picture shows people from very close up. Inherent in it is a certain monumentality which has something to do not only with the size of the people depicted, but also with our own position. Where are we precisely if we extend the space of the picture into the space of the viewer? Are we standing above or below the blind group? This question has no definite answer. If we look at the two falling beggars on the right, we are looking down; if we look at the rest of the group, it seems as though we are looking up. This is a skillful move by the artist designed to unsettle the viewer. Without a firm standpoint we begin to falter, just like the blind men in the picture. In addition, we get the feeling that the tottering blind man with the white cap might be looking at ${ }^{\mathrm{s}} \mathrm{s}$. In a startling way, the artist challenges our traditional notions of seeing versus recognizing, since the eyes of this blind beggar have been gouged out. He is looking at us without being able to see. To put it even more succinctly: the only blind person to look consciously at the viewer most likely did not suffer from an eye disease that caused him to become blind like his comrades; rather, he was blinded. ${ }^{48}$

47 Roberts-Jones P. - Roberts-Jones F., Pieter Bruegel der Ältere (Munich: 1997) ${ }^{233} 3^{\circ} . D$.

48 Regarding individual diseases, see Torrilhon T-M., La pathologie chez Bruegel $[$. dissertation, Faculté de médecine, Paris: 1957). 
Long before there were movie theaters, artists attempted to suggest motion sequences. Even on sarcophagi of the ancient world images were arranged in such a way that one and the same figure was shown in different 'snapshots' of motion. Bruegel's The Fall of the Blind Leading the Blind is one of those attempts to describe an event in different stages of progression. It does so in several ways: following the persons from left to right, it is apparent that they show different psychological moments of the unfolding action. The man on the far left is still walking along confidently, as is evident from the relaxed look on his face. But the facial expression of the person in front of him already indicates a certain unease. The blind man next in line has a startled expression.

In contrast to these characterizations in terms of increasing uneasiness, the three blind men leading the group are characterized by more dramatic motifs of posture and motion, in that the fall of the leader is now beginning to affect the postures of the persons immediately behind him. The upper body of the man in the middle wearing a light-colored cape is jerked forward, as evidenced by his precarious position on the balls of both his feet. Even if he were to let go of the staff joining him to the man in front who has abruptly yanked it forward, he would probably fall, since he has already lost his balance.

It is all over for the next blind man as well. As he falls, he looks in our direction in panic. We see only his right leg, which intensifies the impression of instability. He has let go of the staff of the man ahead of him, groping in vain for something else to hold on to. Finally, the blind man on the far right has already tumbled into the morass of the canal. His arms jolt upwards; his legs flail helplessly. We can see the underside of his left shoe. The back of his head is about to be immersed in the water.

Bruegel shows different psychological reactions to what is happening; at the same time we see motifs of movement expressing different stages of stumbling and falling. Against the background of history painting and its criteria, this work is a masterpiece in the visual rendering of emotions. ${ }^{49}$
Beyond of and that, and preceding all iconographic determinations, this work Bruegel is a showpiece for kinds and degrees of motion. From left to right, ing at express acceleration and compression of a moment in time. Startfeet the latest extreme, with the blind beggar standing on the balls of his and pulled forward by the man in front of him, there is an emphasis

\footnotetext{
${ }^{49} \mathrm{On}$ the problem of depicting emotion in the general context of Italian art theory, Kunsttheorie des 15. und 16. Jahrhunderts (Münster: 1988).
} 
on the precise instant of time, which is further intensified by the men who are actually falling. The artist even omitted painting one of the legs of the second blind man, thus creating the impression of a continuous falling motion among the first two. The cap of the blind man next to the leader is about to fall off his head, yet the latter's fall is not yet completely finished. His legs stick up into the air while the rest of his body is about to be immersed. The picture represents and stages not just a single moment in time, but also compresses the dramatic urgency of this moment. ${ }^{50} \mathrm{Put}$ in modern terms, the last image is a freeze frame, allowing for the capture of a moment of [e]motion.

The Iconography of The Fall of the Blind Leading the Blind

Since the Renaissance, the parable of the fall of the blind has been widely known. Testifying to its great popularity is the fact that it is a background scene in Bruegel's encyclopedic Proverbs painting [Fig. 10]. The Kupferstichkabinett in Berlin contains a drawing formerly attributed to Pieter the Elder but today considered a work of Jacob Savery, also dealing with the subject of blindness [Fig. 11]. ${ }^{51}$ Here, though, the blind man is being led by a seeing person who turns around to look at a woman. Her face is not recognizable under her hat. She appears to be coming from Mass, as indicated by the church spire visible in the background. Whether or not the unchristian attitude of this woman, who has no eyes for those in need, is here meant to be denounced, is unclear. If so, it would mean that a physically blind person is juxtaposed with a morally blind one.

Be that as it may, the subject of the fall of the blind was illustrated a number of times in the immediate environment of the painter. A series of twelve copperplates, probably created after the artist's death, depicts various motifs in Bruegel's work, among them an image of two blind men who tumble screaming into a pit [Fig. 12]. In the surrounding caption, the reader is admonished to pursue his path steadfastly and not to trust anyone but God. Bruegel's son Pieter converted the topic of this copperplate into a painting [Fig. 13]. ${ }^{52}$

${ }^{50}$ On the problem of depicting time, see Müller, Bild und Zeit.

51 Mielke, Pieter Bruegel 82.

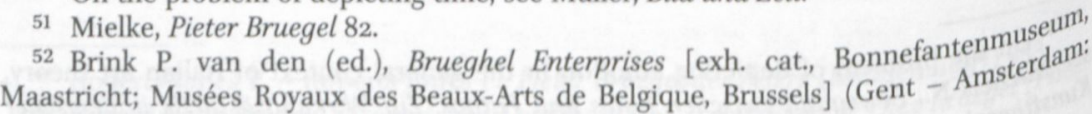
2001) 52 . 


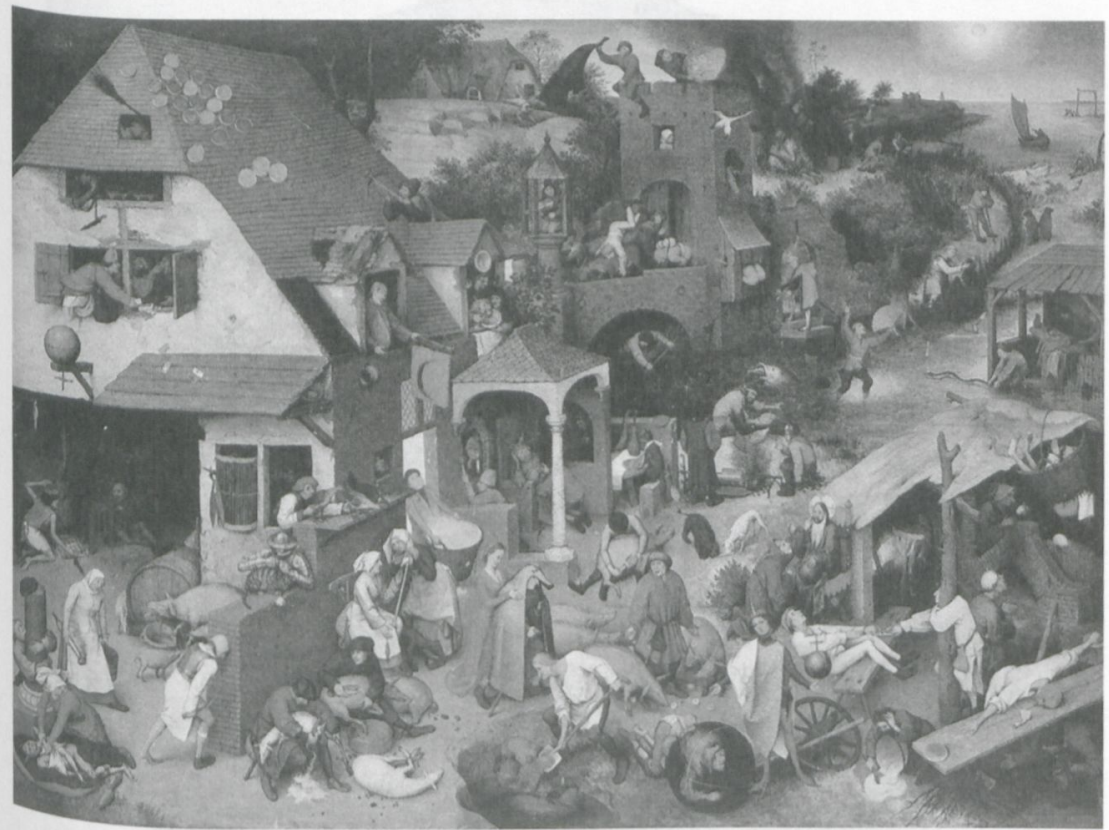

Fig. 10. Pieter Bruegel the Elder, The Netherlandish Proverbs (1559). Oil on panel, $117 \times 163 \mathrm{~cm}$. Berlin, Staatliche Museen, Gemäldegalerie.

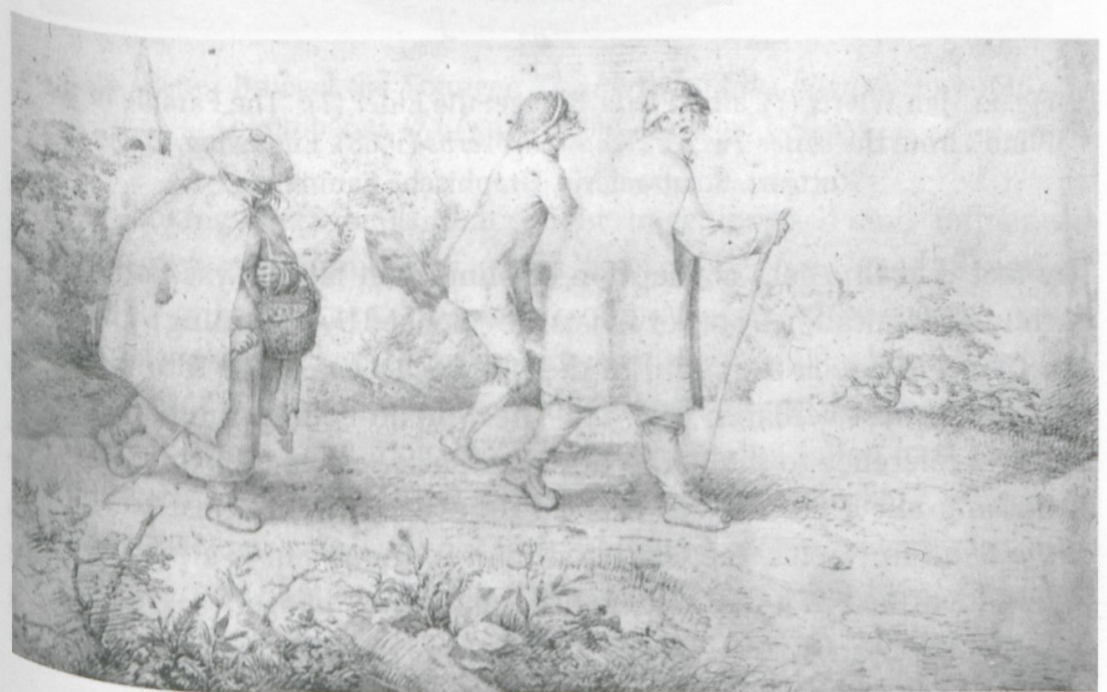

Fig. 11. Jacob Savery, The Blind (1562). Pen and brown ink over black chalk, $192 \times 310$ mm. Berlin, Staatliche Museen, Kupferstichkabinett. 




Fig. 12. Jan Wierix (?), after Pieter Bruegel the Elder (?), "The Parable of the Blind", from the series Twetve Flemish Proverbs (1568). Engraving, $\emptyset 17.7 \mathrm{~cm}$. Stuttgart, Staatsgalerie, Graphische Sammlung.

The fact that Bruegel's conception of blind men falling was famous and encouraged imitation by other artists is evidenced by a painting by Maerten van Cleve, in which the motif of the blind who has fallen into a canal is repeated almost verbatim [Fig. 14]. The woman behind the blind men ${ }^{-}$ clearly a reference to the Berlin drawing - also makes it obvious that this is nothing but a pastiche of Bruegel motifs. But in contrast to the Fall of the Blind in Naples, the last blind man in the group is a pilgrim of $S$. James, identified as a Catholic by his scallop shell badge. ${ }^{53}$

53 On the symbolism of pilgrims, see Ohler N., Pilgerstab und Jakobsmuschel. Wallfahren in Mittelalter und Neuzeit (Düsseldorf - Zurich: 2003) 82-84. 


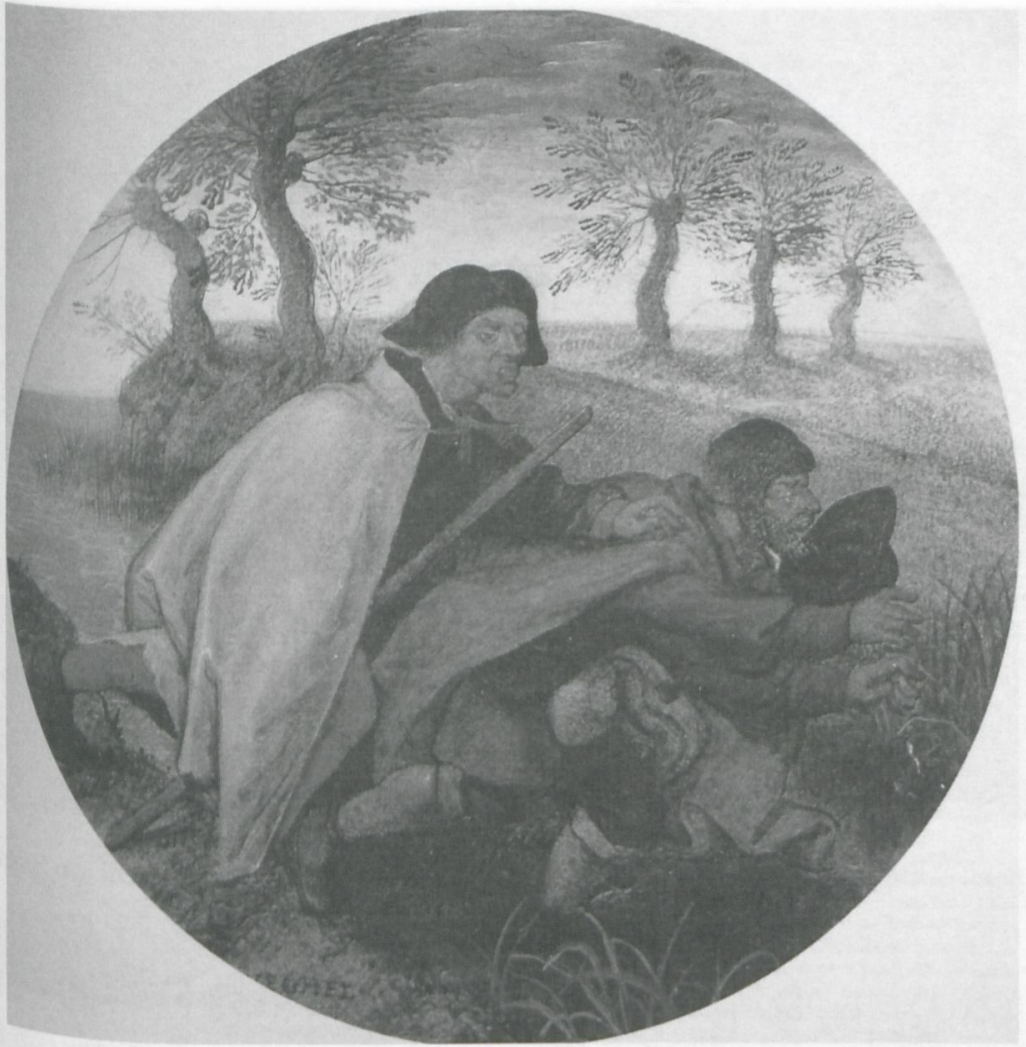

Fig. 13. Pieter Bruegel the Younger, The Parable of the Blind (before 1616). Oil on panel, $\emptyset_{19} \mathrm{~cm}$. Prague, National Gallery. 




Fig. 14. Maerten van Cleve, The Parable of the Blind (after 1568). Oil on panel, $62 \times 84 \mathrm{~cm}$. Private collection.

Wie wol sie beid gefallen synt $\left./[\ldots]]^{\prime}\right)^{55}$ The associated illustration also depicts the fall of the blind, though in this instance they appear to have stumbled over each other rather than into a pit. Another early representation can be found in the Haywain Triptych by Hieronymus Bosch [Fig. 15]; in the bottom left corner of the central panel, we see a man with a child on his back being led by a boy. Larry Silver, among other recent interpreters, has pointed this out and identified the man as blind. ${ }^{56}$ But no matter how one interprets this scene, immediately next to it, vices are featured that undoubtedly apply to this strange pair as well.

Blind beggars can also be found in a representation of Hope, or Spes, by Heinrich Vogtherr dating from the year 1545, which features scenes and persons in need of hope, as explained by the accompanying text [Fig. 16]. An illustration of the Gospel of Luke by Hans Brosamer includes the fall of the blind [Fig. 17]. While Christ preaches to his disciples in the foreground, two blind men can be seen falling down on the right, and on

\footnotetext{
55 Ibidem.

56 Silver L., Hieronymus Bosch (Munich: 2006) 264.
} 




Fig. 15. Hieronymus Bosch, Haywain Tryptich (ca. 1500). Oil on panel, $135 \times 90 \mathrm{~cm}$. Madrid, Museo del Prado. 


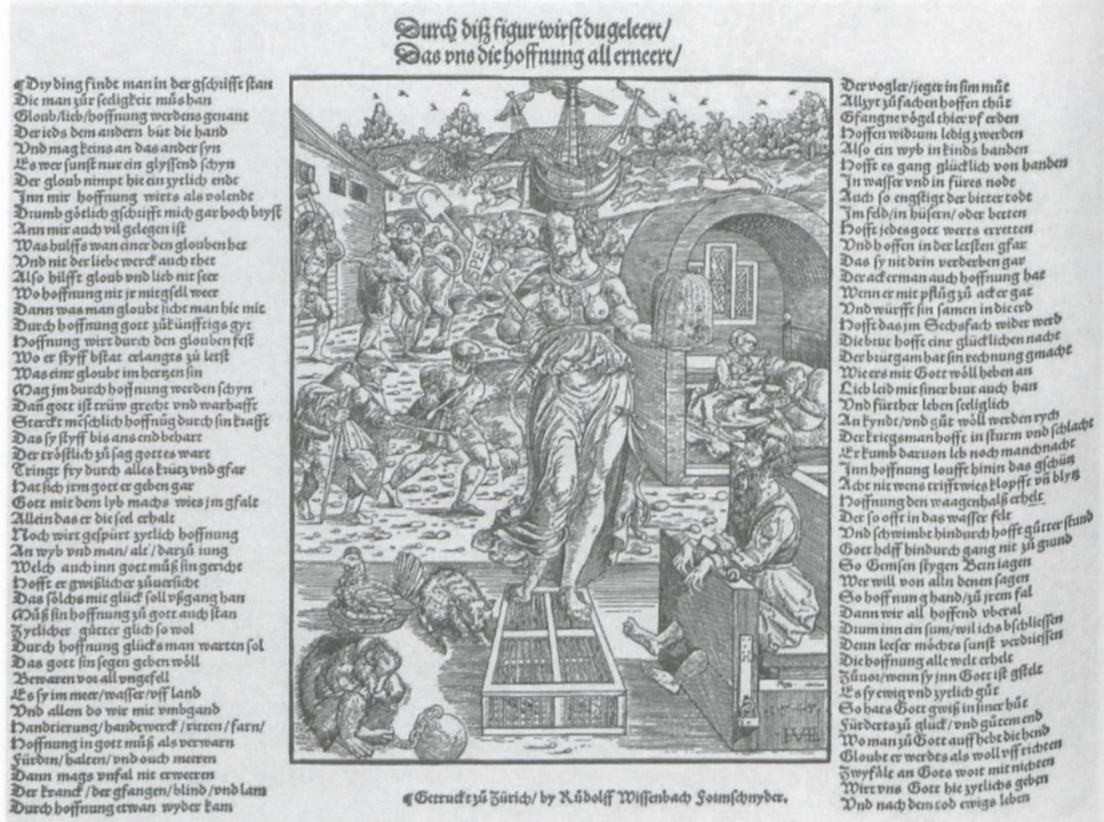

Fig. 16. Heinrich Vogtherr the Elder, Hope (1545). Woodcut, $23.5 \times 33.4 \mathrm{~cm}$. Berlin, Staatliche Museen, Kupferstichkabinett.

the opposite side, the parable of the mote and the beam is illustrated. Virgil Solis also treated this topic in a similar manner. In the center, we can once again identify two blind men falling into a pit [Fig. 18]. The artist was particularly successful in visualizing the evocative power of the words of Jesus: he seems to produce the 'images' before the very eyes of his disciples. Whether Bruegel was familiar with all of these pictures remains an $^{\text {n }}$ open question, however.

But before we pursue the subject of Bruegel's models and their importance for the artist any further, we need to turn our attention to the copies of the picture because they are essential for understanding it properly. Anyone who has ever had an opportunity to study the painting in Naples up close will have noticed the blurred outline of the upper body of a man in front of the church. Due to improper cleaning of the canvas, the top paint layers have suffered serious abrasion, and as a result, some motifs have been rendered barely perceptible. The original body of motives $c^{\text {an }}$

57 This has been established in the secondary literature for quite some time. On the aesthetic issue of pictorial form, see Sedlmayr, "Pieter Bruegel" 319-321. 


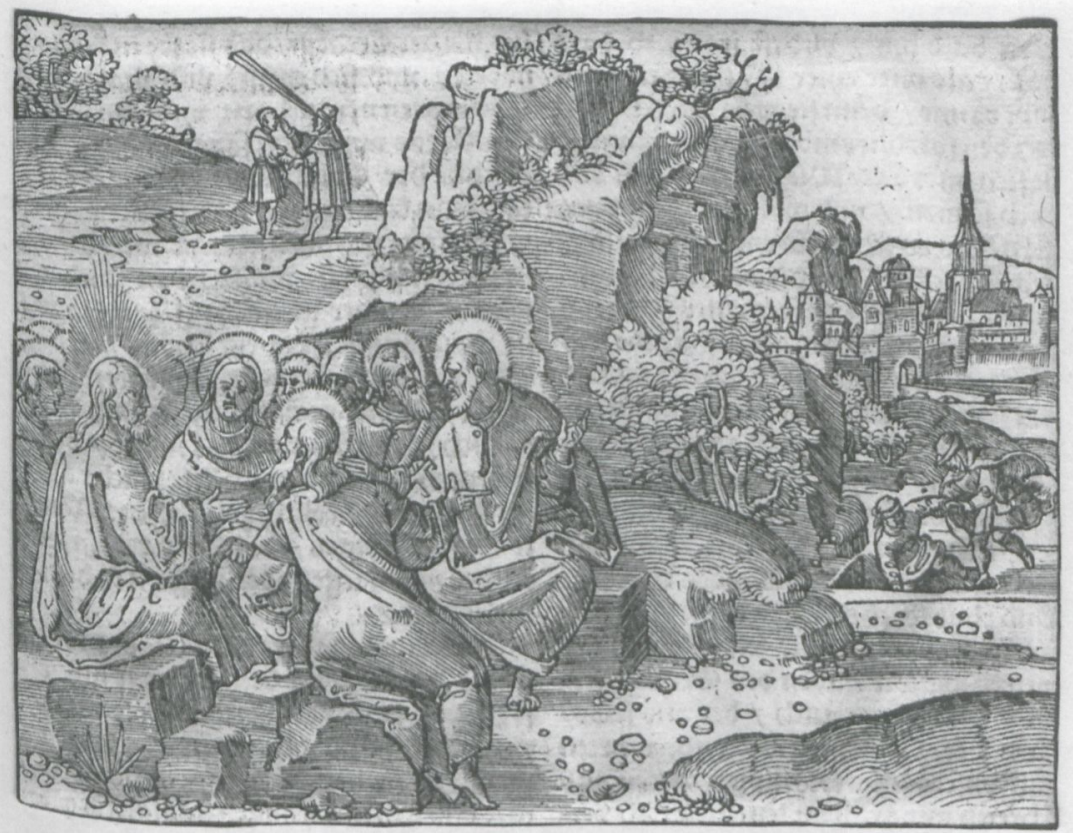

Fig. 17. Hans Brosamer, Illustration to Luke 6:39-41 (ca. 1520-1554). Woodcut, $10.5 \times 14.1 \mathrm{~cm}$. Location unknown.

be reconstructed only by comparing The Fall of the Blind Leading the Blind with copies of the work housed in Paris, Parma, and Vaduz. In doing so, we notice that in the meadow between the church and the blind men there is a man leaning on his staff, who looks toward the group of the blind while herding geese and cows, all the while unaware that one of his cows has wandered off and is about to tumble into a canal. In order to take a drink, it is leaning forward so far that it will fall in at any moment.

The fall of the blind has a thematic counterpart in the fall of the animal; for the viewer, this offers an analogy that permits the identification of the inattentive (viz., faithless) cowherd with the Church. This provides additional support for Stridbeck's thesis that the painting criticizes the Anton. In the context of Stridbeck's interpretation, an engraving by Brunius Wierix deserves mention here; it was executed ten years after subjegel's painting and also has negative examples of false shepherds as its nizablect [Fig. 19]. It is informative insofar as there are two blind men recoga pond in the foreground, who have left the right road and are falling into of the In addition, let me point to the withered and warped tree in front the church, which contrasts with the flowering trees around it. 


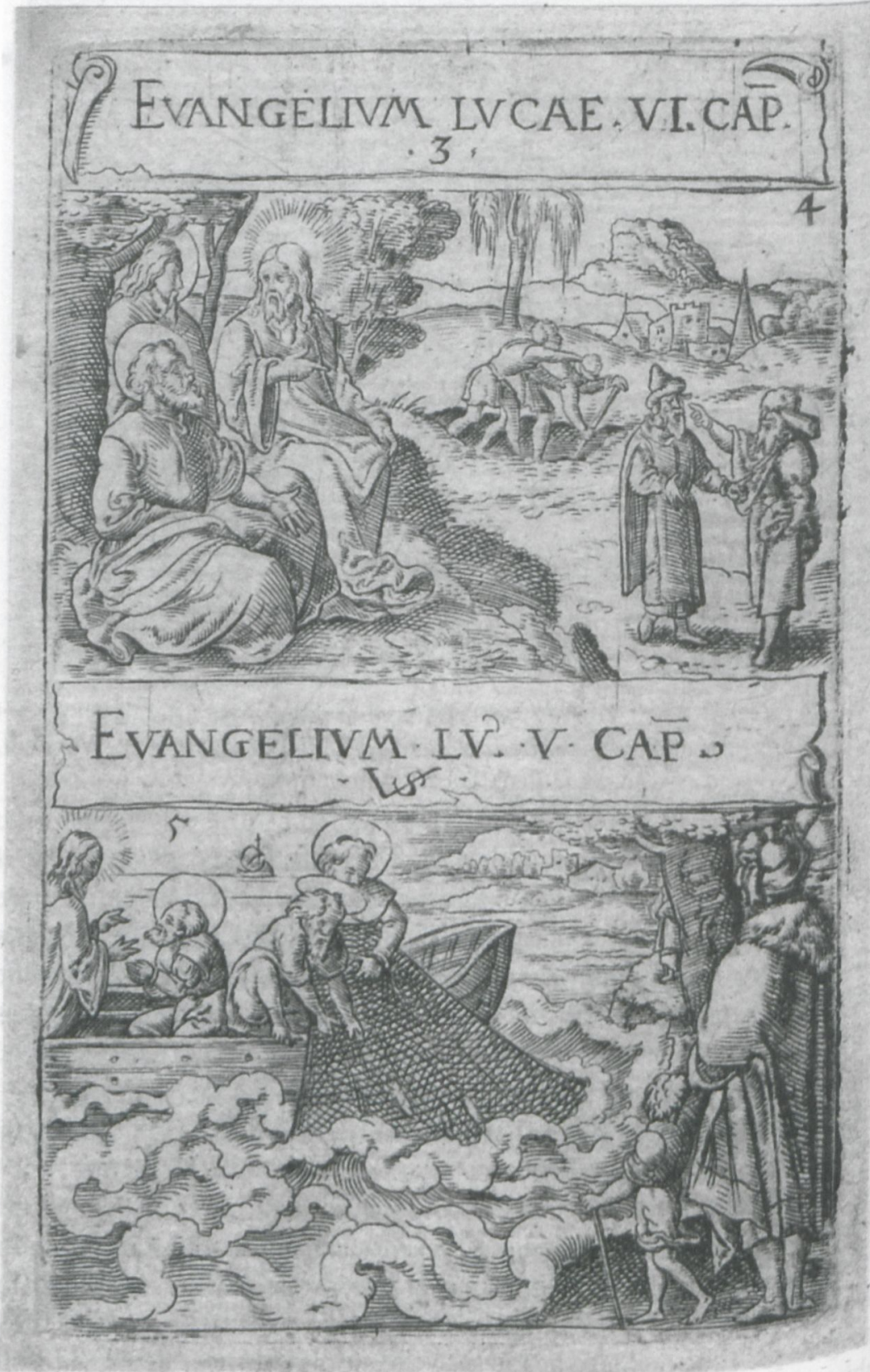

Fig. 18. Virgil Solis, "Luke 6:3", plate 3 of Scenes from the New Testament. Engraving and etching, ca. $7.9 \times 5 \mathrm{~cm}$. Location unknown. 


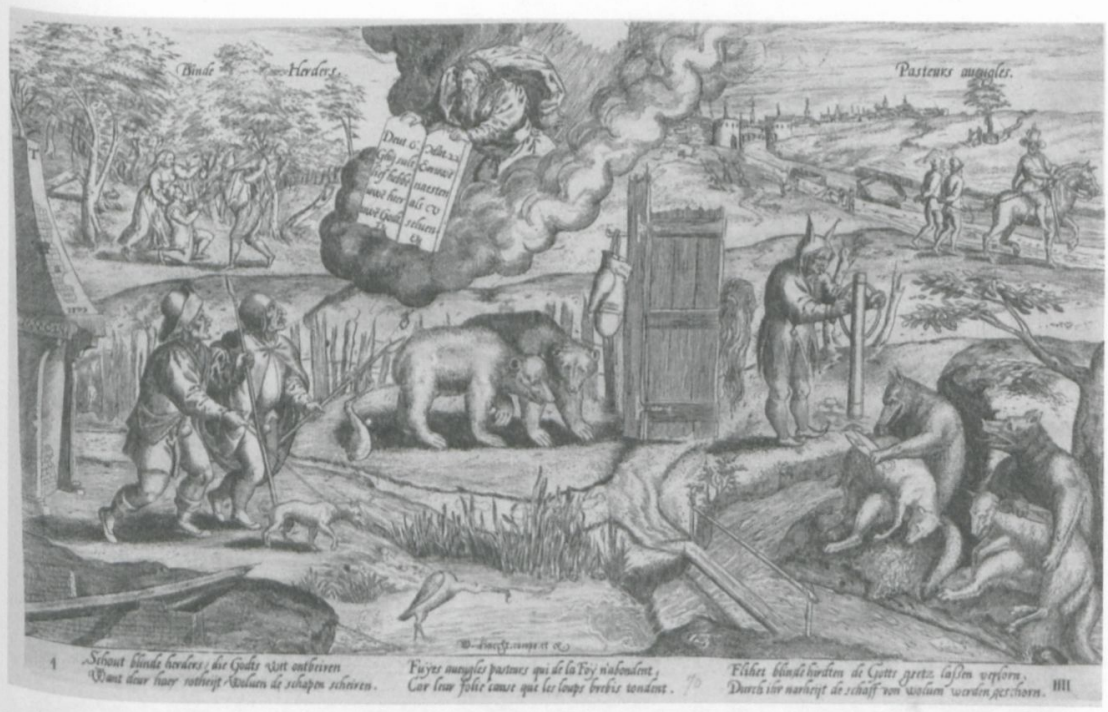

Fig. 19. Antonius Wierix, The Blind Shepherds (1579). Engraving, $20 \times 33.1 \mathrm{~cm}$. Dresden, Kupferstichkabinett.

As regards the copies, we should bear in mind that not a single one was done by Pieter Bruegel the Younger. Most likely, they originated with Italian artists of the seventeenth century whose classicist taste manifests itself in the fact that at the right edge of the picture, they added the hand that was seemingly arbitrarily cut off and raised the top edge of the painting to complete the missing part of the church building. All the copies share as common elements the tree-lined road and the downward-sloping terrain in the foreground.

Repeated references have been made to an undated engraving by Cornelis Massys as a comparative example for Bruegel [Fig. 20]. In this example, the landscape format is entirely taken up by the blind men. Yoreover, Meinolf Trudzinski has cited a woodcut by Hans Holbein the Yunger as an explanatory reference [Fig. 21] ${ }^{58}$ Doubtless, this constistate an interesting source for the painter; it is important, however, to is of differences between the two compositions more clearly. What of interest here is Bruegel's transformation of these sources. A group pope, intectual and spiritual authorities, such as Plato, Aristotle, and the Pope, together with other church dignitaries, have become simple beggars

\footnotetext{
${ }^{58}$ Trudzinski M., "Von Holbein zu Brueghel. 'Christus vera lux, philosophi et papa in

cadentes'", Niederdeutsche Beiträge zur Kunstgeschichte 23 (1984) 63-116.
} 


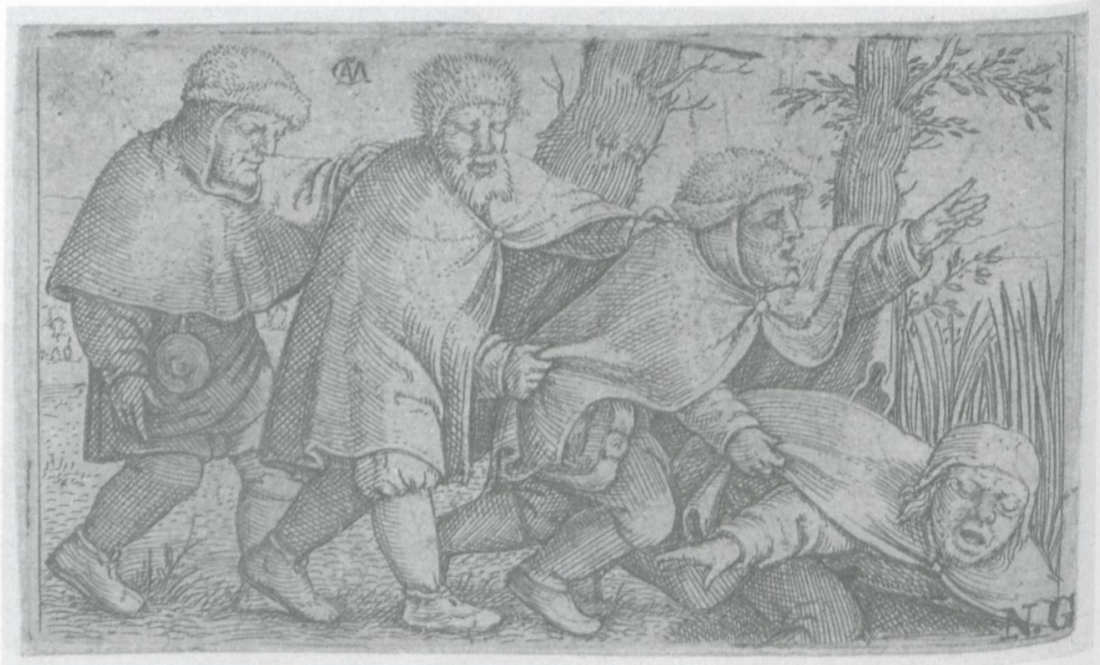

Fig. 20. Cornelis Massys, Parable of the Blind (ca. 1544-1556). Engraving, $4.5^{x}$ $7.6 \mathrm{~cm}$. Amsterdam, Rijksmuseum.

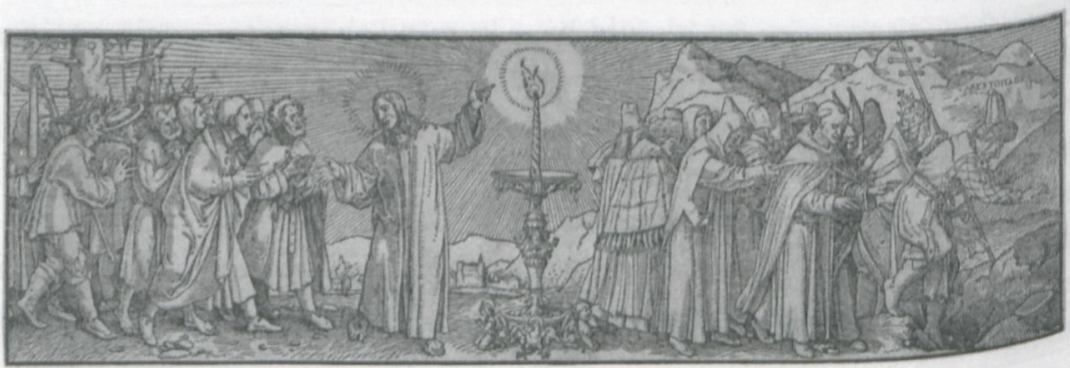

Fig. 21. Hans Holbein the Younger, Christ and the True Light (ca. 1526). Woodcut, $8.4 \times 27.7 \mathrm{~cm}$. Location unknown.

in the painting in Naples. ${ }^{59}$ Moreover, Holbein's Reformation agenda is evident. Congregated at left are simple evangelical followers of Christ, the vera lux, who points to a burning candle, whereas assembled at right are false Catholic dignitaries who fall into the pit despite all their authority and ancient learning. The philosophers represent not only pagan antiq uity, but also the intellectualized faith of Scholasticism. ${ }^{60}$

59 Müller C. (ed.), Hans Holbein d.J. Die Druckgraphik im Kupferstichkabinett Basel [exth. cat., Kupferstichkabinett Basel) (Basel: 1997) 16.

60 Hofmann (ed.), Luther und die Folgen für die Kunst 187. 


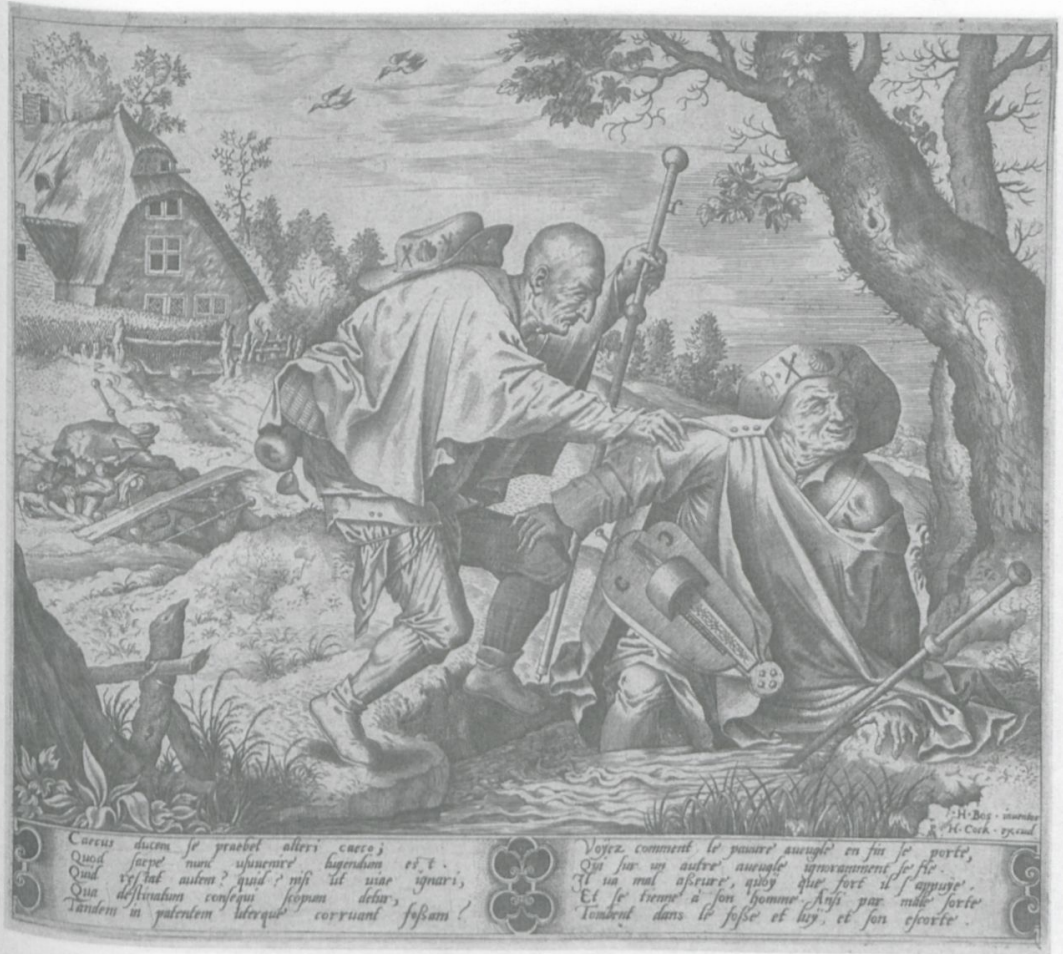

Fig. 22. Pieter van der Heyden, after Hieronymus Bosch (?), Parable of the Blind (ca. 1540-1570). Engraving, $22.2 \times 25.5 \mathrm{~cm}$. Location unknown.

Contrary to Trudzinski's view, this woodcut was probably less significant as a direct model. Nevertheless, it importantly serves as a reminder that the iconography of the fall of the blind was confessionalized during the Reformation. This confessional reinterpretation is confirmed in an engraving by Pieter van der Heyden that has been linked to Hieronymus Bosch, since 'Bos' is named on the print as its inventor [Fig. 22]. Two Catholic pilgrims, recognizable by their emblems, are falling into a canal. The scal${ }^{10} \mathrm{p}$ shells on the brims of their hats are clearly identifiable. Actually, a fall takes place twice: figures in the middle ground are falling after having not the is based on a painting by Hieronymus Bosch, this is actually again case; on the contrary, Heinke Sudhoff has shown that this is once Amsterin a pastiche, and that the faces of the two pilgrims are taken from the sterdam Christ Crowned with Thorns by Bosch [Fig. 23]. ${ }^{61}$

\footnotetext{
${ }^{61}$ Sudhoff H., Ikonographische Untersuchungen zur 'Blindenheilung' und zum 'Blinden'. Ein Beitrag zu Pieter Bruegels Neapler Gemälde von 1568 (Bonn: 1981) 118-120.
} 




Abb. 23. Hieronymus Bosch, Christ Crowned with Thorns (1511). Oil on panel. Amsterdam, Rijksmuseum.

Our brief iconographic overview makes it clear that the biblical parable was utilized long before Bruegel. It might be fair to assume that the motif of the falling Catholic pilgrim dates back to the time of the Reformation. One of the earliest examples I have been able to find in this regard is a drawing from the British Museum attributed to Hans Weiditz and dated sometime in the 1520 s [Fig. 24]. ${ }^{62}$ The pen-and-ink drawing shows two blind men, one of whom is clearly recognizable as a pilgrim. Furthermore, the motif of the missed bridge is already prefigured here. To my mind, this motif alludes to the biblical passage in which Christ answered Thomas saying, 'I am the way, the truth, and the life'. ${ }^{63}$ If we situate Bruegel's painting in the context of the images represented, what stands out is the fact that 62 Groß S., Hans Wydyz. Sein Oeuvre und die oberrheinische Bildschnitzkunst (Hildes
heim: 1997).

63 John 14:6. 


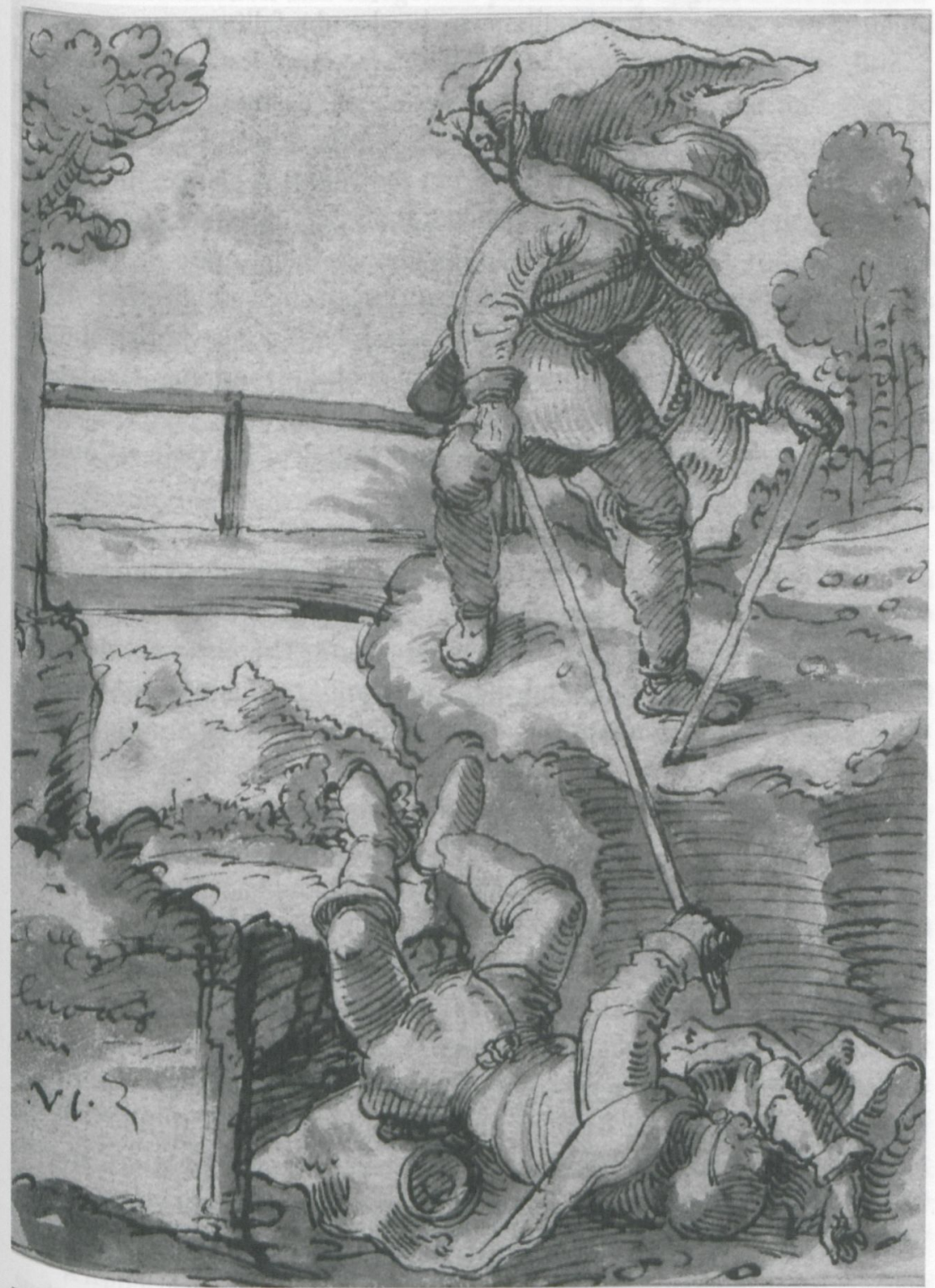

Fig. 24. Hans Weiditz (previously attributed to Tobias Stimmer), Parable of the Blind (ca. 1520). Pen and black ink, with grey wash and traces of red chalk, $15.1 \times 11.5 \mathrm{~cm}$. London, British Museum, Department of Prints and Drawings. 
he expanded the established pattern of two or four blind men. ${ }^{64}$ Moreover, none of the pictures includes such a prominently featured church building or a scene with a heedless cowherd and a falling cow.

Still, such a great number of comparative examples have been cited by now that we are better able to describe the aesthetic characteristics of the Bruegel painting. What makes his composition of The Fall of the Blind Leading the Blind so unique? From the very first glance, the subject of his painting appears more ambivalent than that in other compositions, due to the fact that it is difficult to decide whether we are dealing with a genre painting or a history painting. Although the actual source of the painting is a biblical parable, we would certainly be somewhat hesitant to classify it as a history painting because of that. Furthermore, though we are confronted with maimed human beings, they are not representations of martyrs, as would be required by the art theory of the Italian CounterReformation. ${ }^{65}$

Finally, as regards the formal aspects, the artist takes great pains to treat a genre painting as a history painting. Thus, he has bridged the two categories by transferring a theme typical of a print onto canvas and changing a small format into an extremely large one. The close-up view and the monumentality of the blind men contribute to this upward revaluation, leaving no doubt about the artist's skill in portraying emotion, facial expression, gesture, and movement.

Yet these formal enhancements are juxtaposed with the obviously lowly content of the picture: it is simply not appropriate for a history picture to portray maimed human beings whose handicaps are literally $\mathrm{put}^{\mathrm{t}}$ in the limelight. Here, a passage from Alberti's De pictura comes to mind, in which the Italian art theorist ponders the portrayal of a ruler, demanding that a king who lost an eye in war should be portrayed in profile so $a^{s}$ not to detract from his dignity. ${ }^{66}$ Alberti's example attests to the demand that decorum be observed, a prescription that does not appear in the least to have impressed Bruegel. Paradoxically, the artist fulfilled all the requirements of a history painting and nevertheless did not create one. Ultimately, the question of whether we are dealing with a history painting

64 Sudhoff, Ikonographische Untersuchungen zur 'Blindenheilung' und zum 'Blindenstur' 137. 137.
65 Cf. here the detailed list of sources regarding Italian Cinquecento art theory in Settis ${ }^{\text {.. }}$
Laocoonte. Fama e stile (Rome: 1999). Laocoonte. Fama e stile (Rome: 1999).
66 Alberti L.B., Della Pittura - Über die Malkunst, eds. O. Bätschmann - S. Gianfreda
(Darmstadt: 2010) 131. 
or a genre painting must be left unanswered. To my mind, this deliberate dehierarchicalization and categorical permeability appear to be constitutive of the master's art. ${ }^{67}$

\section{The Fall of the Blind as a Denunciation of Dissenters}

It hardly needs stating that a reference to the parable of the blind leading the blind can be found in the writings of all the major reformers. The topic of the fall of the blind was of special interest during the Reformation since it concerns the matter of emphasizing one's own legitimacy with respect to other confessions. ${ }^{68}$ Early on, in his programmatic tract To the Christian Nobility of the German Nation, Luther had identified the Roman Catholic clergy and the Pope as guides of the blind. ${ }^{69}$ But in later texts, as well, the German reformer called the Pope a 'Roman guide of the blind' ('romisch Blindenführer'). ${ }^{70}$

Long before Luther, Erasmus of Rotterdam used this parable in his Handbook of a Christian Knight, dating from 1503. In order to make clear to his readers the consequences of a Christian life, the Dutch theologian writes: 'I have no doubt that even now those foolish wise men and blind leaders of the blind are yelling at you that you are mad because you are ready to follow Christ [...]. Their miserable blindness ought to be mourned rather than imitated'. ('Ich zweifle nicht, dass schon jetzt dir voll Hass jene törichten Weisen und blinden Führer der Blinden entgegen schreien, dass du rasend seiest, weil du bereit bist, Christus nachzufolgen. $[\because$.$] Ihre erbärmliche Blindheit ist eher zu beweinen als nachzuahmen'. ]^{71}$

${ }_{68}^{67}$ Müller, Das Paradox als Bildform 90-125.

Rome to Silvio Piccolomini, in a retractation bull dated 26 April 1463 , wrote thus from our to the University of Cologne: We walked in darkness and, not being content with falling error, we also pulled others into the abyss serving as blind leaders to the blind and selbst verinto the pit with them.' ('Wir sind im Finstern gewandelt, und nicht zufrieden, uns Blinden zerirrt zu haben, haben wir noch andere in den Abgrund gezogen und als Blinde den see Piccolom Führer gedient und sind mit ihnen in die Grube gefallen.') For this passage, ${ }_{69}$ A colomini E.S., Briefe. Dichtungen, trans. M. Mell (Munich: 1966) 224.

Studien A reprint of the original text with a critical commentary is included in Martin Luther ${ }_{70}$ Dr.

Schriften. Martin Luther's sämtliche Werke. Reformationshistorische und polemische deutsche Roman , ed. J.K. Irmischer (Erlangen: 1830) 142: 'We still do not see, so completely did the Blindenfuide of the blind capture us.' ('Noch sehen wir nit, so gar hat uns der romisch

${ }^{71}$ Erasmus D., "Handbüchlein eines christlichen Streiters”, in idem, Ausgewählte Schrif-
ten. Lateinisch/Deutsch, Vol. einisch/Deutsch, Vol. 1, ed. W. Welzig (Darmstadt: 1990) 103. 
And later Erasmus implores the reader once again to follow the light: 'Leave it $[\ldots]$ to the blind to lead the blind and fall into the pit together.' ('Lass du [...] die Blinden die Blinden führen und zugleich in die Grube stürzen'. $)^{72}$

For Erasmus, the guides of the blind are usually those persons who keep us from resolutely following Christ. However, in his preface to the Bible, the "Ratio verae theologiae", he uses the image of the fall of the blind with self-critical intention when talking about his edition of the New Testament. ${ }^{73}$ Sebastian Franck uses the parable along the same lines, stating in his Paradoxa of 1534: '[...] that is none of your concern; come and follow me. Christ says: "Leave them, they are blind guides of the blind"'. ('[...] was geht es dich an, komm du und folge mir nach. Da spricht Christus: "Lasset sie, sie sind blinde Blindenführer"'. $)^{74}$ Finally, John Calvin, in the preface to his 1543 hymnal, admonishes all believers that if they wish truly to appreciate the worship service as a whole and in its parts, they must rely upon God to illuminate them, lest they be left to their own devices, to their 'own understanding' ('eigenenVerstand') and the 'foolish wisdom $[\ldots]$ of blind leaders' ('tollen Weisheit [...] blinde[r] Führer'). ${ }^{75}$

Furthermore, the secondary literature on Bruegel's Fall of the Blind Leading the Blind often cites literary texts referring to the fall of the blind that might possibly have served as sources of inspiration. For the most part, however, this is limited to short quotes that simply document, in the final analysis, the parable's widespread currency in the sixteenth century. Marijnissen, in particular, lists numerous sources from $155^{\circ}$ to $15^{25}$, including both religious treatises and rederijker verse dramas, ${ }^{76}$ but char- $^{-5}$ acterizes these texts as entirely conventional, adding that they provide $\mathrm{n} 0$ deeper understanding of the picture. ${ }^{77}$ Heinke Sudhoff is the only scholar to have posited a specific text as central, maintaining that Bruegel's paint ${ }^{-}$ ing directly reacts to a play by Dirck Volkertszoon Coornhert. In this context, she interprets blindness as a metaphor of the Stoic-Christian moral philosophy, but otherwise misconstrues the painting's iconography.

This list could go on indefinitely, but suffice it to say that there are probably few parables besides the parable of the fall of the blind that were quoted with such frequency in order to slander the other confessional

72 Ibidem 269 .

73 Erasmus D., "Theologische Methodenlehre", in Ausgewählte Schriften 121-123.

${ }^{74}$ Franck S., Paradoxa, ed. S. Wollgast (Berlin: 1966) 293.

75 Jenny M., Luther, Zwingli, Calvin in ihren Liedern (Zurich: 1983) 271-281.

76 Marijnissen. - Seidel, Bruegel 365-366.

77 Ibidem 365 . 
position. By slandering the other party, one assigned the position of true believer to oneself. From this perspective, orthodoxy would have need of heterodoxy. Yet neither the writings of the reformers nor the other literary sources have thus far proved helpful in securing a more precise understanding of Bruegel's picture.

In order to determine the possible relevance of additional models, it is first of all necessary carefully to consider one of the painting's most important formal devices. To my mind, this device proves consequential to the way he represents the church. The church spire is truncated by the edge of the Tüchlein, and this prevents the cross at its pinnacle from being represented. This strange detail is why some interpreters have gone so far as to surmise that the picture might have been trimmed at its upper edge. Migroet and Marijnissen, however, have strongly rejected this hypothesis, pointing out that The Fall of the Blind Leading the Blind preserves the black border typical of a Tüchlein painting. ${ }^{78}$ This empirical finding surely demonstrates that the picture was never trimmed. Why then did the artist incorporates this peculiar detail, cutting off the cross at the top of the church tower? This question is crucially important.

Pieter van der Heyden's The Parable of the Blind of 1561 , engraved after Hans Bol, provides a useful point of reference [Fig. 25]. (Cited by Heinke Sudhoff in her dissertation, it played no part in her subsequent interpretation.) The print portrays two pilgrims of St. James, along with a man carrying a child on his back. The latter could well be a Jewish hawker or beggar. ${ }^{79}$ His fur cap, known by its Polish name spodik and typical of Eastern Jews, identifies him as such. ${ }^{80}$

In this context it is important to observe the blind man with his dog, in the left middle ground, who has stopped at the large house in order to beg. Bol clearly matched the shape of this building to the church building in the background, even though the former is a brothel, as can be seen from the couple hugging in the upper window.

\footnotetext{
${ }_{79}$ Marijnissen. - Seidel, Bruegel 365 .

Terms for and visualizations of the 'Handels- or Trödeljuden' ('trading Jews') have a

pushed tradition. The use of the term dates back to the Middle Ages when Jews, having been

also to out of the traditional economic system, were limited to money lending, and later

$\left.{ }^{19} 9_{2}\right) 183$. 80183.

Ostjuden Somogyi T., Die Schejnen und die Prosten. Untersuchungen zum Schönheitsideal der

sidismus in Bezug auf Körper und Kleidung unter besonderer Berücksichtigung des Chas-

attention (Berlin: 1982) 137ff. I gratefully acknowledge Martin Przybilski, who called my tion to spodik of the Eastern Jews.
} 


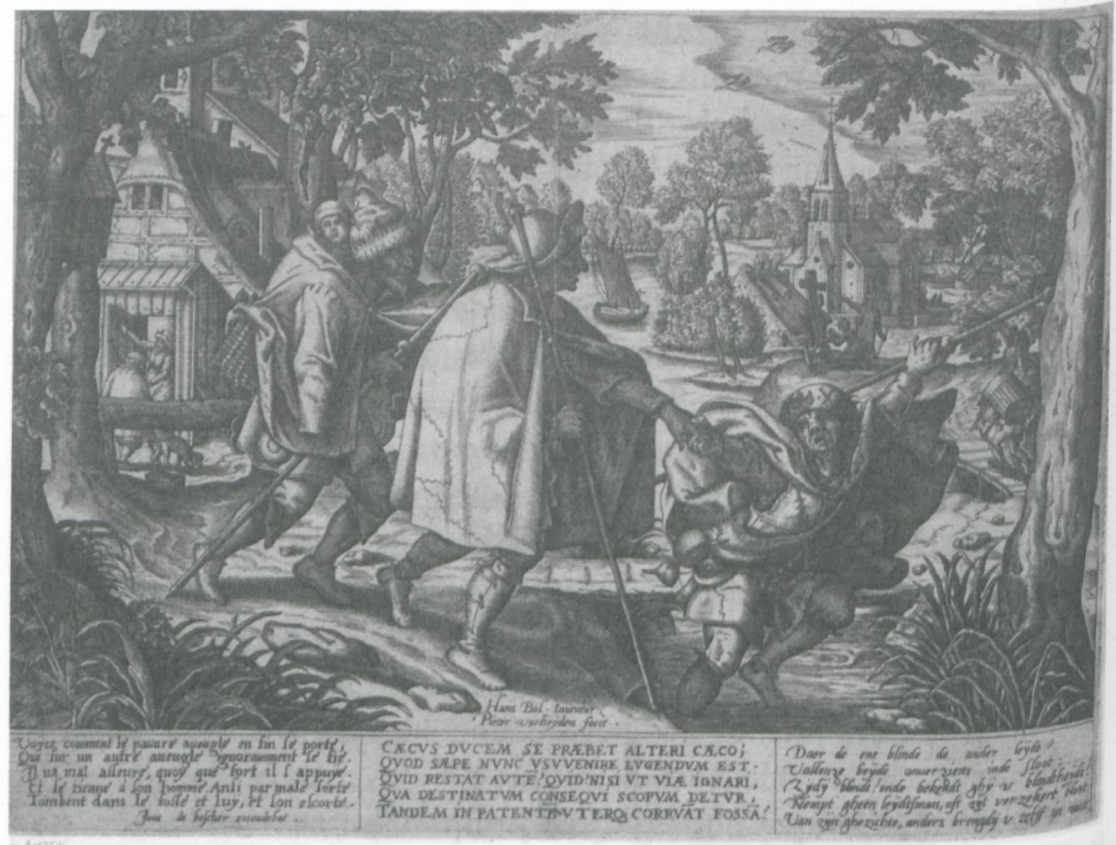

Fig. 25 Pieter van der Heyden, after Hans Bol, Parable of the Blind (1561). Engraving, $21.8 \times 29.6 \mathrm{~cm}$. Location unknown.

In contrast to the comparanda cited thus far, the engraving after Bol sets positive examples against negative ones. In the background, two people have stopped to pray at a wayside cross. The dark stone cross stands out distinctly due to its placement on the vertical axis of the picture, with the nearby church pointing up the promise of redemption by divine grace. In addition, in the left foreground there appears a small shrine, familiar to us from Bruegel's Peasant Dance as well as Brant's Ship of Fools, which the blind men have bypassed [Fig. 26]. Bol is making it plain to the viewer that the blind men are oblivious the shrine's Christian message, whereas the people devoutly praying in the background are on the right path to God. The fact that these people, unlike the blind men, have found salvation is also emphasized by the nearby image of a ship. ${ }^{81}$

Also on the right path toward the cross is a heavily burdened man about to traverse a small footbridge and reach the other believers pray ing in front of the church. Here reference should be made to the third cross located on the church tower. The church with its cross is explicitly

${ }^{81} \mathrm{Cf}$. in this context my remarks about 'Zwei Affen', in Müller, Das Paradox als Bildform 




Fig. 26. Pieter Bruegel the Elder, The Peasant Dance (ca. 1568). Oil on panel, $114 \times 164 \mathrm{~cm}$. Vienna, Kunsthistorisches Museum.

placed in opposition to the blind men. In Bol's iconographic scheme, the cross consistently functions as an indication of the true faith, whereas its absence signifies transgression and deviation from the true path.

It is precisely this function of the cross as a reference to true faith, which is not to be found in Bruegel's picture. By his curious elision of this pictorial detail, the artist forces the issue of the cross's absence. More than this, he makes the viewer look this absent symbol of assured salvation. In Bruegel's composition, unlike Bol's, the cross does not appear as a sign indicating the orthodoxy of the good Christian, and nor does it set the orthodox believer in opposition to the errant blind men. On the contrary, the cross is simply another object carried by the blind: second man from the left is wearing one around his neck, but this does not keep him from losing his way or falling. Bruegel even seems subtly to be raising the question of symbolic legitimacy, for the blind man's cross, even though Present, is as good as absent.

\section{Negative Theology and Spiritualism} Given the observations made thus far, does it not follow that Bruegel's Fall
of the Blind Leading the Blind should be read as an account of how difficult 
it is to find God in this life? His picture points out the insufficiency of the cross as mere appurtenance, as an ornament hanging from the blind man's neck. 'Deus quid sit, nescitur', or 'No one knows what God is', is the programmatic title of the first paradoxon in the Sebastian Franck's Paradoxa. ${ }^{82}$ In formulating this paradox, Franck turns against all religions that try to comprehend God in a representational mode. ${ }^{83} \mathrm{He}$ demands a radical rejection of all images in favor of a mystical experience of God that directs us inward. The theologian from Donauwörth, at the end of this first paradoxon, warns and implores his readers: '[...] As long as man is dealing with images, he cannot turn to the spirit and to that which is in him. [...] You must forsake all images and turn to God in the depth of your soul; there you will find God, for the kingdom of God is within you!' ('[...] Alldieweil und solange der Mensch mit Bildern umgehet, kann er zu dem Gemüt und zu dem, was in ihm ist, nicht einkehren. [...] Ihr müsst allen Bildern den Abschied geben, zu Gott einkehren in den Grund der Seele, da sollt Ihr Gott finden, denn das Reich Gottes ist in Euch!') ${ }^{84}$

With some justification, Hans Sedlmayr featured the opposition between Ecclesia and Synagoga in his interpretation of The Fall of the Blind Leading the Blind, ${ }^{85}$ stating that the stone church can be seen to confront the false teachings of heretics, as represented by the blind men. In the statuary art of medieval cathedrals, the triumphal cross of the Church is traditionally contrasted with the broken insignia of the Synagogue, the personification of which is characterized as blind, her eyes veiled. Yet what may appear compelling and plausible in this structural opposition, is precisely what Bruegel challenges. A closer look at his composition reveals the presence of an upside-down Latin cross, formed as though by chance at the end of the single file of blind beggars. The cross that is usually carried at the head of a procession, as a powerful symbol of victory, has instead become a fleeting impression, a momentary alignment of forms soon to pass.

With reference to blind Synagogue and the allusion to heretical teaching, it is essential to adduce Sebastian Franck's Chronica, Zeytbuch und geschychtbibel, published in 1531and translated into Dutch as early as $155^{8 .}{ }^{86}$ The "Ketzerchronik", included in this compendium, constitutes an

82 Franck, Paradoxa 17. 82 Franck, Paradoxa 17.
83 On Franck's rejection of representational media, see Bietenholz, Encounters with a
Radical Erasmus $13-31,69-93$.

${ }^{84}$ Franck, Paradoxa 21.

85 Sedlmayr, "Pieter Bruegel" 17.

86 Franck Sebastian, Chronica, Zeytbuch vnd geschychtbibel (Strasbourg, Balthasar Beck: 1531). 
integral part of the Geschychtbibel. In his preface, the German theologian states that the reader should not assume that everyone he is about to enumerate is a heretic, ${ }^{87}$ for such a judgment would sooner reflect not the author's opinion, but that of the Pope. On the contrary, his thesis is that the judgment of others is what creates heretics in the first place. If it were up to him, everything would be reversed, and heretics would be declared saints.

He goes on to say that there are many who ended up in the 'sooty cauldron' ('rußigen Kessel') of the Pope, whom he considers worthy of immortality. If it were left to the Bohemians, the Pope and his apostles, not Jan Hus, would appear on the list of heretics. Christians, Franck goes on to argue in his preface, have been heretics at all times and in all places, an assertion he follows by listing renowned heretics. ${ }^{88}$

It is the nature of the world time and again to interchange good and evil, so that only truly spiritual persons are capable of discerning how true Christianity is expressed in the truth of heresy. The difference between heresy and the true Church does not reside in dogmatic content as such, but in the status of such content. According to Franck, the drama of heresy, or better, the martyrdom of heresy, started with the fact that the official churches fell short of fulfilling their Christian identity because they replaced spiritual identity with institutional authority. Heresy takes place only from the perspective of church authority that declares itself absolute, as he claims. ${ }^{89}$

One can hardly imagine a more radical assertion than Franck's, who considered Christ the first heretic and true Christians as standing in this heretical tradition. Even so, he was under no illusion concerning the actual state of things, as is evident when he says: 'If nowadays the Pope or any other supposedly evangelical [sic] sect should sit in judgment on the heretics, exactly the same thing would happen: one sect would persecute and hate the other to death [...]. That is a certain destiny and characteristic of the Gospel and the Truth'. ('Sollten nun zu unseren Zeiten der Papst oder irgendwelche angeblich evangelische [sic] Sekten über die Ketzer urteilen, so würde es genauso zugehen, wie es eben zugeht, dass eine
Sekte die andere bis in den Tod hasst [...]. Das ist ein gewisses Schicksal

${ }^{87}$ Ibidem 233.
${ }_{88}$ Franck, Chronica, Zeytbuch vnd geschychtbibel 234.
${ }^{89}$ Ibidem $235^{-237 .}$ 
und Erkennungszeichen des Evangeliums und der Wahrheit'. ${ }^{90}$ For Franck, history from the days of the apostles to Judgment Day is forced to repeat itself: 'Wherever Christ makes himself felt, there are Judas, Caiaphas, Annas, Pilate, and as ever, the entire Passion'. ('Wo sich Christus nur regt, da findet sich Judas, Hannas, Kaiphas, Pilatus und stets die ganze Passion'. $)^{91}$

To put it boldly, Bruegel's Fall of the Blind Leading the Blind illustrates this view of the world. He presents a positive assessment of heresy, here (as elsewhere) following Sebastian Franck's ideas. ${ }^{92}$ Like the author of the preface to the 'Ketzerchronik', the Flemish artist, against expectation, does not take the confrontation of orthodox Church and heresy as his starting point. Quite the opposite, in The Fall of the Blind there is no incompatibility between Ecclesia and Synagoga, but rather a fluid transition. The blind man on the far left may be taken positively to represent a seeker after God, whereas the attributes of the other men, whose fall appears inescapable, increasingly point to the rites of the official churches. The Church itself is ultimately exposed as guide to the blind.

Against the background of Franck's positive evaluation of heresy, Bruegel's image of the blind appears in a new light. We are urged to learned that as regards knowledge of God, all mankind is blind and resistant to change. The only way God can be experienced is within the heart, beyond all knowable images, all tangible reality. From this perspective, the staff of the blind operates as an ambivalent symbol. As long as it functions as a metaphor of the search for God and brings to mind the fact that, in principle, all knowledge is only partial, it carries a positive meaning and serves as a radical metaphor of the fundamental impossibility of knowing God fully. If you believe, however, that it can steer one onto the right path, and mistakenly take it for a reliable guide - as if it were possible to grope one's way toward God - things will turn out badly, as can easily be seen. The search for God is bound to fail whenever and wherever God is sought externally.

This ambivalent valuation of the blind as they who seek and err is indirectly confirmed if we refer to a 1571 copperplate based on a sketch by Bruegel, which shows the disciples en route to Emmaus. It is no $\mathrm{co}^{\mathrm{in}^{-}}$

90 Cf. Fast (ed.), Der linke Flügel der Reformation 240; Wagner A., Das Falsche der Religionen bei Sebastian Franck. Zur gesellschaftlichen Bedeutung des Spiritualismus der rad len Reformation (Ph.D. [digitale] dissertation, Freie Universität, Berlin: 2007) 371-447.

91 Fast (ed.), Der linke Flügel der Reformation 236.

92 This is the subject of my monograph on Bruegel, Das Paradox als Bildform. 
cidence that one of the two Emmaus disciples reminds us of the blind beggar at the far left edge of the Tüchlein picture. The pedagogical intent is obvious: not only blinded people and heretics are unable to recognize Christ, but even his disciples fail to do so. They will be able to recognize him only in a spiritual and eucharistic sense, when he breaks the bread with them at the inn. In addition, the walking staffs of the two men are not crossed. For Bruegel, the Catholic pilgrims of St. James have become seekers after God, unaffiliated with any confession. In the copperplate, then, the artist has essentially stripped his subject of confessional references.

This can be said also to apply to Bruegel's Fall of the Blind Leading the Blind. Expressly absent from the picture is any alusion to the superiority a specific confession: Bruegel refrains from claiming the sole legitimacy of any confession, nor does he downgrade competing denominations, deriding them as mere guides to the blind. On the contrary, he stages an allusive commentary critical of the Churches. Viewed in light of ironicspiritualist theology, his narrative of the fall of the blind is less about personal transgression than about the fall of Christian religion. Whenever it mistakes itself for an unimpeachable institution with sole claim to the legitimate representation of the divine will, it becomes a guide to the blind. Looking at the blind beggars in this, we are invited to take a critical stance toward the second one from the left, who wears a rosary around his neck. The rosary hanging from the belt of the third man from the right is another hint at the veneration of the Virgin Mary. The aspiration to draw close to God has been reduced to mere tokens of an externalized and presumptuous faith. For Franck, the Fall of Man continues when people build churches, believing that they can externalize their faith and substituting empty signs for the fullness of divine truth. ${ }^{93}$ The church that is built out of bricks and mortar, stucco and stone, is the real guide of the blind!

In his Paradoxa, Franck speaks forcefully against the fallen state of a Christianity that disregards its spiritual nature. ${ }^{94} \mathrm{He}$ describes its decline as an inevitable process, as if the true, invisible church needed to be disPersed and persecuted from the moment of its inception in the days of
the apostles. The 234th paradoxon is entitled: "The Church, a lily among thorns, is scattered among pagans and trampled on until the end". ("Die

\footnotetext{
${ }^{93}$ This is the title of the 89 th paradoxon: "Temples, images, celebations, sacrifices, and monien do not belong in the New Testament". ("Tempel, Bilder, Feste, Opfer und Zere142. $\quad$ gehören nicht ins Neue Testament".) For this paradoxon, see Franck, Paradoxa 94 Ibidem $347-35^{2}$.
} 
Kirche, eine Lilie unter Dornen, wird unter den Heiden zerstreut und bis zum Ende zertreten". $)^{95}$ Bruegel seizes on this metaphor. On the right, above the canal and the falling blind man, there is a blooming water lily. The canal itself is hard to see. Almost without transition, its swampy surface merges into the adjoining bushes and brownish meadow, an optical 'trap' also used by Bruegel in The Peasant and the Birdnester and based on the same plant imagery. In that picture as well, the lily is a symbol of the true Church.

In conclusion, I want to call attention to one additional pictorial detail that has escaped scholarly notice. Bruegel would not be Bruegel if he did not also positively convey a message about humility. His viewers might otherwise have gone on, getting along comfortably in a world full of religious fallacies and believing that they might be spared such a fall. But the picture, rather than allowing this status quo ante, makes an admonitory point aimed discreetly at the viewer. As described earlier, the church spire is cut off at the upper edge of the picture. However, it is precisely this missing section that is visible on the horizon to the left of center beyond the hill. The trees in the immediate vicinity demonstrate the scale of this part of the building. In other words, the artist has the missing section of the church tower reappear somewhere else.

The church spire beyond the hill becomes an axis for the events in the foreground. It separates the group of people who are already falling from those who might perhaps still fall. It marks the point where there is still hope that those at the end of the row might let go of one another and thus avoid falling into the morass. Is it stretching a point to say that this might be intended as a warning to the viewer? He is in the same position as the third man from the left who may or may not fall; with respect to him, as also to us, we cannot be sure of the outcome. Be that as it may, if the self-confident viewer presumes to disassociate himself from those who are falling, this will errantly put himself in danger of falling eventually. Therefore, he too is under the influence of the church beyond the hill, which though invisible to him, is nevertheless powerful. The question is not whether or not others will fall, but whether or not we will fall. And so, the viewer would be wrong to place himself above the unfortunate blind men in the foreground, because he, like them, runs the risk of following heedlessly in the footsteps of a blind guide. 
Let us return once more to Franck's letters translated into Dutch at the beginning of the 1560 s. As regards theology, they repeat ideas that could have been familiar to an adherent of the German theologian from his other writings. But what makes these letters especially interesting is how clearly they advocate a Nicodemic strategy. ${ }^{96}$ The fact that the letters were translated at this point in time emphasizes how urgent this problem was thought to be.

Advocating Nicodemism, however, was not without risk, as is evident from a passage in which Franck expressly asks his addressee Campanus to handle the letter carefully so as not to turn himself into a martyr. ${ }^{97} \mathrm{He}$ explicitly warns the recipient not to let his letter fall among 'dogs and Swine' ('Hunde und Säue'), lest he prepare a 'premature cross' ('vorzeitiges Kreuz') for himself, for many are led to the gallows by their imprudent and ill-timed idle talk. ${ }^{98}$ This practice of secrecy even receives theological justification when he briefly states that God himself hides his wisdom 'under the cloak of parables and in mysterious letters' ('unter der Decke der Gleichnisse und Parabeln der Buchstaben') that cannot be understood 'by anyone other than those who have been taught by God himself' ('von niemand als von denen, die von Gott selbst gelehrt'). ${ }^{99} \mathrm{He}$ advises caution, counseling that one should only speak when and where it is appropriate to do so.

In view of all that has been said, it must seem obvious that Bruegel's Fall of the Blind Leading the Blind in a richly encypted image. The wealth of allusions is such that one can surely claim that it resists easy interpretation. Yet the iconographic program, as I have tried to show, is not at all propagandistic: quite the contrary, it partakes of qualities readily associated with subtle theological discourse. The heterodox content in the picture is dissembled; an heretical interpretation is a possibility lurking just beneath its surface.

Taking up once more the question of Bruegel's pictorial hermeneutics in The Fall of the Blind Leading the Blind, it is important to stress that the artist treats artistic tradition in a very unconventional way. He cues the ver not so much to facilitate understanding of his picture, but rather

incarcerated; a certain sense, this also applies to Campanus, since he spent a large part of his life

The ologited; see "Johannes Campanus", in Hofmann K. - Buchberger M. (eds.), Lexikon für

${ }_{99}$ Fas und Kirche, Vol. 2 (Freiburg - Basel - Vienna: 1994) 914. Fast (ed.), Der linke Flügel der Reformation 233.
} 
to generate misunderstanding. Expressed in modern terms, this could be called a transcriptive procedure. He is using tradition in a purposely critical way. ${ }^{100}$ Utilizing existing iconographic traditions, the artist is suggests certainties that prove, upon reflection, to be elusive. He is using prior models in an unconventional way. Bruegel does not draw on themes, types, or motifs in order to continue a tradition of meaning, but in order to question it. Yet he does this in a very subtle way, which is discernible only at a secondary level of meaning. This Umschreibeverfahren, or transcription procedure, as I would like to call it, needs to be ascertained, because the relationship between pictures is generally affirmative in nature. The Flemish artist takes a different approach. He points to models in order to contradict, or at least question, their supposed truth content. He embraces traditions in order to prove them wrong from within. In doing so, the artist does not just contradict certain statements; rather, he goes beyond them by questioning the validity of the very value system they represent.

Bruegel's strategy is to lay out everything in the picture without expressing himself unequivocally. At no time does the narrative mode of his picture relinquish latency. It is only when the beholder manages to connect the significant elements that an added hermeneutical value is created. Seen individually, all these details - the truncated church tower, the cross worn by the blind man, the rosary of another, the cowherd, the cow falling into the ditch, the spire beyond the hill, the open space in front of the church, the blind man reminiscent of an Emmaus disciple, and the dead tree in front of the cowherd - would seem to be accidental. But taken aggregatively or, better, as a whole, these elements are like steps leading to a higher level of meaning: the new meaning to be created can only be attained proactively. If I link the existing elements correctly, meanings may develop that point beyond what is actually shown. Yet the creator of the picture always retained for himself of rejecting all this as a misrepresentation. To put this in linguistic terms, I misunderstand the picture if I confuse parole with langue, if I believe that an argument legitimzing orthodoxy is, of necessity, configured into the fall of the blind; this assumption must be interrogated, in spite of the fact that it appears to be confirmed, at least initially, by the parabolic and proverbial imagery of blind men falling into a ditch. ${ }^{101}$

100 Müller, "Ein anderer Laokoon" 389-455. 100 Müller, "Ein anderer Laokoon" 389-455.
101 Saussure F. de, Cours de linguistique générale, ed. R. Englert, 2 volumes. (Wiesbadent
$1967-1974)$ I 36-39. 
As we have seen, blindness and the fall of the blind have been defining and exclusionary metaphors of orthodox Christianity at all times. In contrast with all other interpretations, my conclusion in reading The Fall of the Blind Leading the Blind is that the artist is questioning the assumption that the true Church and heresy are mutually exclusive. Thus I am inferring an illuminative-ironic intention in Bruegel's painting. In it, the exclusionary principle of denunciation is itself being criticized. The picture describes, in the form of an allegory, how the Christian religion begins as an innocent search for God; how it comes to be externalized in symbols, rites, and official churches; and how it ultimately loses its way and falls.

In conclusion, it behooves me to state that the goal of this article is not to impart specialized iconographical knowledge. Instead, my intention has been to discuss the potentiality of Bruegel's visual strategies that have as their goal the communication of religious ideas standing outside the Catholic Church. My reflections on orthodoxy and heresy are not meant to perpetuate the cliché of artists as society's outsiders. Quite the contrary, I start from the assumption that up to the time of the Council of Trent, religious 'deviance' (in the sense of non-conformity) was more common than we have been led to believe by an art historiography oriented toward strict opposition between the confessions. ${ }^{102}$ Finally, let me remind you that we must not value the esthetic experience of Bruegel's painting any less than the historical 'information' it conveys. What comes to mind here is something that Jacob Burckhardt once expressed so well that a successful work of art is like an arrow that flies through the centuries. Concurring with the well-known Swiss historian, I have tried to show tow Bruegel's Fall of the Blind Leading the Blind gives us privileged access to the transgressiveness implicit in much early modern art. Whoever looks has the empty eyes of the falling blind man will not easily forget what he an in seen. After all, in these dead eyes we recognize not only the horror of an impending fall but also the sudden realization of our own culpability. 


\section{Selective Bibliography}

BARnes B.A., Michelangelo in Print. Reproductions as Response in the Sixteenth-Century (Farnham: 2010).

BERGMANN R., "A tröstlich Picture: Luther's Attitude in the Question of Images", Renaissance and Reformation 5 (1981) 15-25.

BERNS J.J., "Die Macht der äußeren und der inneren Bilder. Momente des innerprotestantischen Bilderstreits während der Reformation", in Battafarano I.M. (ed.), Begrifflichkeit und Bildlichkeit der Reformation (Bern: 1992) 9-37.

BIETENHOLZ P.G., Encounters with a Radical Erasmus: Erasmus' Work as a Source of Radical Thought in Early Modern Europe (Toronto: 2009).

BRANT S., Narrenschiff, ed. F. Zarncke (Darmstadt: 1964).

BRINK P. VAN DEN (ed.), Brueghel Enterprises [exh. cat. Bonnefantenmuseum, Maastricht; Musées Royaux des Beaux-Arts de Belgique, Brussels] (Ghent - Amsterdam: 2001).

Busch E. - Heron A. et al., Calvin-Studienausgabe, Vol. 3. Reformatorische Kontroversen (Neukirchen-Vluyn: 1999).

ERASMUS D., "Handbüchlein eines christlichen Streiters", in idem, Ausgewählte Schriften. Lateinisch/Deutsch, Vol. 1, ed. W. Welzig (Darmstadt: 1990).

- "Theologische Methodenlehre", in idem, Ausgewählte Schriften. Lateinisch/Deutsch, Vol. 3, ed. W. Welzig (Darmstadt: 1990).

FAST H. (ed.), Der linke Flügel der Reformation. Glaubenszeugnisse der Täufer, Spiritualisten, Schwärmer und Antitrinitarier (Bremen: 1962).

FrancK SEBAStian, Chronica, Zeytbuch vnd geschychtbibel (Strasbourg, Balthasar Beck: 1531).

- Paradoxa, ed. S. Wollgast (Berlin: 1966).

Freedberg D., "Allusion and Topicality in the Work of Pieter Bruegel: The Implications of a Forgotten Polemic", in idem (ed.), The Prints of Pieter Bruegel the Elder [exh. cat.. Bridgeston Museum of Art, Tokyo] (Tokyo: 1989) 53-65.

—, "The Life of Pieter Bruegel the Elder", in The Prints of Pieter Bruegel the Elder [exh. cat. Bridgeston Museum of Art, Tokyo] (Tokyo: 1989) 21-31.

Grossmann F., Pieter Bruegel. Gesamtausgabe der Gemälde (Herrsching: 1973).

HARMS W., Homo viator in bivio. Studien zur Bildlichkeit des Weges (Munich: 1970).

Hegler A., Beiträge zur Geschichte der Mystik in der Reformationszeit, ed. W. Köhler (Berlin: 1906). (Berlin: 1906).
HoFmann W., Luther und die Folgen für die Kunst [exh. cat. Hamburger Kunsthalle, Ham-
burg] (Munich: 1983).

IMDAHL M., Giotto. Arenafresken: Ikonographie, Ikonologie, Ikonik (Munich: 1988) 99-110.

JENNY M., Luther, Zwingli, Calvin in ihren Liedern (Zurich: 1983).

Kascheк B., Weltzeit und Endzeit. Die 'Monatsbilder' Pieter Bruegels d.Ä. (Munich: 2012).

Kavaler E.M., Pieter Bruegel: Parables of Order and Enterprise (Cambridge: 1999).

LUPI W.F., "La scuola dei Sileni", Festschrift für Eugenio Garin (Pisa: 1987) 1-20.

ManN Philipps M., The 'Adages' of Erasmus: A Study with Translations (Cambridge: 1964)

MARIJNISSEN R.H. - SEIDEL M., Bruegel. (New York: 1984).

Michels N., Bewegung zwischen Ethos und Pathos. Zur Wirkungsästhetik italienischer

Kunsttheorie des 15. und 16. Jahrhunderts (Münster: 1988).

Mielke H., Pieter Bruegel. Die Zeichnungen (Turnhout: 1997).
Milla-Villena R., "Deux Moralités de Pierre Bruegel l'Ancien à l'Époque de la Montée

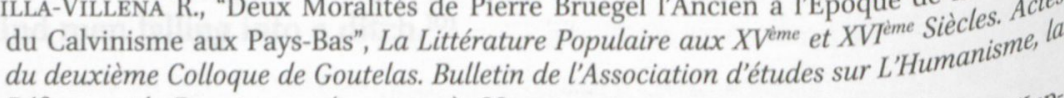
Réforme et la Renaissance (n.p.: 1979) 188-195. Réforme et la Renaissance (n.p.: 1979) 188-195.
MülLER C., Hans Holbein d.J. Die Druckgraphik im Kupferstichkabinett Basel [exh. cat., Kup'
ferstichkabinett Basel] (Basel: 1997). ferstichkabinett Basel] (Basel: 1997).
MüLLER J., "Von der Odyssee eines christlichen Gelehrten - Eine neue Interpretation vo"
Hans Holbeins Erasmusbildnis in Longford Castle", Zeitschrift des deutschen Vereins fir
Kunstwissenschaft 49/50 (1995/96) 179-211. 
_, "'Pieter der Drollige' oder der Mythos vom Bauern-Bruegel”, in Ertz K. (ed.), Pieter Breughel der Jüngere, Jan Brueghel der Ältere: flämische Malerei um 1600 (Lingen: 1997) 42-53.

_ des Bethlehemitischen Kindermordes", Morgen-Glantz: Zeitschrift der Christian Knorr von Rosenroth-Gesellschaft 8 (1998) 273-296.

_ , "Bild und Zeit. Überlegungen zur Zeitgestalt in Pieter Bruegels 'Bauernhochzeitsmahl' ", in Pochat G. (ed.), Erzählte Zeit und Gedächtnis: narrative Strukturen und das Problem der Sinnstiftung im Denkmal (Graz: 2005) 72-81.

_ , "Ein anderer Laokoon - Die Geburt ästhetischer Subversion aus dem Geist der Reformation", in Kellner B. - Müller J.D. - Strohschneider P. (eds.), Erzählen und Episteme: Literaturgeschichte des späten 16. Jahrhunderts (Berlin-New York: 2011) 389-455.

$\bar{M}$, Das Paradox als Bildform. Studien zur Ikonologie Pieter Bruegels d. ̈. (Munich: 1999).

MÜLLER W.G., "Das Problem von Schein und Sein in Erasmus' Sileni Alcibiadis und Shake-

Speares Macbeth", Wolfenbütteler Renaissance-Mitteilungen 15 (1991) 1-18.

MÜNCH B.U., Geteiltes Leid. Die Passion Christi in Bildern und Texten der Konfessionalisierung. Druckgraphik von der Reformation bis zu den jesuitischen Großprojekten um 1600 (Regensburg: 2009).

ICHOLS T., The Art of Poverty: Irony and Ideal in Sixteenth-Century Beggar Imagery (Manchester: 2007).

NOLL T., "Pieter Bruegel d.Ä. Der Bauer, der Vogeldieb und die Imker", Münchner Jahrbuch der Bildenden Kunst 50 (1999) 65-106.

PFEIFFER H., “Gemalte Theologie in der Sixtinischen Kapelle. Die Fresken des Michelangelo Buonarotti ausgeführt unter Julius II", Archivum historiae pontificiae 31 (1993) 69-107.

RICHER H., Griechische Mythen in christlicher Deutung (Darmstadt: 1966).

Richardson T., Pieter Bruegel the Elder. Art Discourse in the Sixteenth-Century Netherlands (Farnham: 2011).

SCHWRTS-Jones P. - RoBerts-Jones F., Pieter Bruegel der Ältere (Munich: 1997).

in RHOFF G., "Gottlosigkeit und Eigensinn. Religiöse Devianz in der Frühen Neuzeit", in Vorländer H. (ed.), Transzendenz und Gemeinsinn. Themen und Perspektiven des Dresdner Sonderforschungsbereichs 804 (Dresden: 2010) 58-63.

SEDLNER R.W., "Reformatorische Bildpropaganda", Historische Bildkunde 12 (1991) 83-106. Hefte H., "Pieter Bruegel: Der Sturz der Blinden. Paradigma einer Strukturanalyse",

Sefte des Kunsthistorischen Seminars der Universität München 2 (1957) 1-49.

cura MENCHI S., Erasmo da Rotterdam: Adagia. Sei saggi politici in forma di proverbi, a Cura di Silvana Seidel Menchi (Turin: 1980) 60-119.

SOMIS S., Laocoonte. Fama e stile (Rome: 1999).

MOGYI T., Die Schejnen und die Prosten. Untersuchungen zum Schönheitsideal der Ostju-
mus Bezug auf Körper und Kleidung unter besonderer Berücksichtigung des Chassidis-

STEC (Berlin: 1982).

STRIDBE W., Bruegel, trans. H. Frank (Cologne: 1974).

ter Bruegel d. Ä. sowie dessen Beziehungen zum niederländischen Romanismus (StockSUDH: 1956).

Ein Beitr., Ikonographische Untersuchungen zur 'Blindenheilung' und zum 'Blindensturz'.

$S_{\text {BESMA J., "The Reception }}$ in



Cadentes'”, "Von Holbein zu Brueghel. 'Christus vera lux, philosophi et papa in foveam

$V_{\mathrm{E}_{\mathrm{EN}}}{ }_{\mathrm{C}}$ M.G.K.', Niederdeutsche Beiträge zur Kunstgeschichte 23 (1984) 63-116.

$V_{\mathrm{IT}_{\mathrm{T}}}$ nicodemieten in het bijzonder met Coornhert (Houten: 2001).

[exh. (ed.), Der Glanz der Farnese. Kunst und Sammelleidenschaft in der Renaissance. cat., Haus der Kunst, München] (Munich: 1995). 
WAGner A., Das Falsche der Religionen bei Sebastian Franck. Zur gesellschaftlichen Bedeutung des Spiritualismus der radikalen Reformation (Ph.D. [digitale] dissertation, Freie Universität, Berlin: 2007).

WARNKE C.P., Sprechende Bilder, sichtbare Worte. Das Bildverständnis in der Frühen Neuzeit (Wiesbaden: 1987).

WEIGELT H., Sebastian Franck und die lutherische Reformation (Gütersloh: 1972).

Zagorin P., Ways of Lying: Dissimulation, Persecution, and Conformity in Early Modern Europe (Cambridge: 1990). 